\title{
Artelogie
}

Recherche sur les arts, le patrimoine et la littérature de l'Amérique latine

17 | 2021

Transformaciones en Cuba contemporánea: cultura y sociedad

\section{Biopolítica, higienismo y poder: el caso del noticiero "Ecuador Noticiero Ocaña Film 1929".}

Xavier Puig Peñalosa

\section{OpenEdition}

Journals

Edición electrónica

URL: https://journals.openedition.org/artelogie/10399

DOI: 10.4000/artelogie.10399

ISSN: $2115-6395$

Editor

Association ESCAL

Referencia electrónica

Xavier Puig Peñalosa, «Biopolítica, higienismo y poder: el caso del noticiero "Ecuador Noticiero Ocaña Film 1929".», Artelogie [En línea], 17 | 2021, Publicado el 12 octubre 2021, consultado el 15 septiembre 2022. URL: http://journals.openedition.org/artelogie/10399; DOI: https://doi.org/10.4000/artelogie. 10399

Este documento fue generado automáticamente el 15 septiembre 2022.

All rights reserved 


\title{
Biopolítica, higienismo y poder: el caso del noticiero "Ecuador Noticiero Ocaña Film 1929".
}

\author{
Xavier Puig Peñalosa
}

\section{A modo de prólogo}

1 Es sabido que toda imagen responde a una voluntad de representación, es decir, de etimológicamente- "poner a la vista" determinados significados y mensajes que articulan un discurso de sentido en función de su propio contexto histórico, cultural, ideológico, etc., al tiempo que vehicula la transmisión de, por ejemplo, una determinada y particular cosmovisión (creencias, valores o ideas) referida, en la mayoría de los casos, a su lugar de enunciación (sociedad, clase social, etc.).

Entre las muchas películas, cortometrajes, documentales, reportajes o noticiarios que la Cinemateca Nacional del Ecuador tiene en su interesante y pedagógica página web de libre visionado on-line (http://www.cinematecanacionalcce.com ), figura el noticiero "Ecuador Noticiero Ocaña Film 1929"1 (también denominado "actualidades" en la época). Dicho noticiero y en relación a lo expresado anteriormente, a mi juicio simboliza a través de sus imágenes, una hegemónica concepción sobre/de la sociedad por parte de las élites ecuatorianas $\mathrm{y}$, más particularmente quiteñas de finales de los años veinte. Dicha concepción y muy sintéticamente sería la correspondiente a una sociedad disciplinada, a la par que disciplinaria, y que respondería a los "valores" que constituyen el término civilización, siempre y según lo enuncian e interpretan dichas élites.

3 En este sentido, debe señalarse en primer lugar que dicho término -mejor, categoríaestablece una clara dicotomía entre civilización y barbarie o, lo que es lo mismo, entre progreso y atraso. Así y aunque dicha dicotomía halla su apogeo a partir del segundo tercio del siglo XIX con el colonialismo occidental en África y Asia principalmente, su ulterior desarrollo en los proyectos nacionales que se establecen en los países 
latinoamericanos por sus respectivas élites a raíz de su independencia de las colonias, será fundamental para justificar la hegemonía política, económica y social de aquellas sobre las propias poblaciones y, de modo especial, sobre la de los diversos pueblos y culturas aborígenes "nacionales". Al tiempo, se pretenderá la integración de estos a dicho proyecto mediante la invisibilización o la negación de sus idiosincracias, bien por la vía evangelizadora (salesianos en el caso del Ecuador), bien por la vía escolar y/o pedagogizante (escuelas primarias o de alfabetización y de "concienciación nacional"), cuando no por el puro exterminio (terratenientes, paramilitares, caucheros en la Amazonía, etc.), justificado y amparado por una supuestamente manifiesta inferioridad racial y cultural.

4 En segundo lugar, cabe así mismo referirse a la categoría de civilización como sinónimo de modernidad, a saber, todas aquellas cuestiones que referidas a la innovación (novedad), particularmente a las tecno-científicas, operen como afianzadoras de ese progreso que define y caracteriza a la propia civilización; y entre aquellas y como se desarrollará a los efectos del presente escrito, descuellan muy especialmente una serie de prácticas pertenecientes al ámbito de la biopolítica y su consiguiente "administración de poblaciones" (Foucault, 2007) que, como el higienismo o la policía (Kingman, 2008; Kingman, 2010: 123-154; Kingman, 2014: 27-112; Luzuriaga, 2010: 31-56) ${ }^{2}$, caracterizarán al período -años veinte del propio siglo-, tal y como nos muestran las imágenes del noticiero "Ecuador Noticiero Ocaña Film 1929".

5 Finalmente y en tercer lugar, a partir de la primera década del siglo XX, la implementación y desarrollo del sistema capitalista -financiero e industrial- a nivel prácticamente global mediante la profundización y ampliación de un mercado mundial ya creado en el siglo anterior y ahora con fuertes características monopolísticas, supondrá la aplicación de unas específicas relaciones de producción que, no sin resistencias por parte de las clases trabajadoras mediante sus propias organizaciones sindicales y/o políticas, marcarán y condicionarán indefectiblemente la subsiguiente diacronía histórica de las naciones-estado, ahora sometidas a una nueva concepción geopolítica en el plano internacional, a saber, la de los imperios (Ortiz, 1990: 11-54; Alperin, 2005: 207-358; Cueva, 1987), al tiempo que a fuertes tensiones internas en el propio ámbito nacional, producto de los enfrentamientos de clase.

6 En conclusión, estas tres cuestiones tendrán una importante incidencia en el Ecuador de los años veinte, al tiempo que muchos aspectos relativos a las dos primeras hallarán su concreción en el noticiero que nos ocupa -fundamentalmente en su segunda parte- $y$, siendo por tanto, el objeto de análisis en el mismo.

\section{El Ecuador Noticiero Ocaña Film 1929 (Primera parte)}

7 La década de los años veinte supone un considerable auge en la producción nacional cinematográfica -noticieros, reportajes y argumentales-, merced tanto al establecimiento de alianzas entre diversos sectores económicos como al apoyo gubernamental, muy interesado este último especialmente en el género de los noticieros ("actualidades") pues, se trataba de mostrar que "en Sudamérica existen repúblicas debidamente organizadas y no pueblos al margen de la civilización". En definitiva, la finalidad era evidenciar mediante la producción de esas imágenes pues ello atraería capitales extranjeros al país, que también el Ecuador participaba de esa ideología de 
progreso y modernidad, fundamento del concepto de civilización líneas arriba ya enunciado (Granda, 1995:64).

8 Es en el anterior contexto donde el fotógrafo de origen español Manuel Ocaña y afincado en primera instancia en Guayaquil y posteriormente en Quito, realiza en esta última ciudad su noticiero Ecuador Noticiero Ocaña Film en 1929 y en formato de $35 \mathrm{~mm}$. con soporte de nitrato de plata y de una duración de 23'04", aunque anteriormente ya había realizado otros siete del mismo género de "actualidades" (Granda,1995:103-112). En el que nos ocupa, Ocaña lo divide merced a su montaje, en dos partes claramente delimitadas y un pequeño epílogo que, a mi juicio y como ya comentaré, obra de síntesis simbólica de todo lo anteriormente expuesto. Conviene destacar desde la óptica del lenguaje cinematográfico que Ocaña tiene un exquisito gusto al filmar y montar su documental, particularmente en la composición de los planos. Así y en estos, vemos que el realizador utiliza tanto diversos tipos de planos (panorámicos, generales, medios, etc.) con sus correspondientes encuadres (frontales, diagonal izquierda y/o derecha, etc.), creando perspectivas muy sugestivas o acertadas profundidades de campo o, la profusa utilización de los barridos laterales, todo ello en función de poder mostrar la mayor cantidad posible de información con una meditada economía de lenguaje (número de planos), al tiempo que variedad en la forma de mostrarla (montaje). En síntesis, ello denota un profundo conocimiento de la estética cinematográfica por parte de Ocaña, cuestión poco habitual en los realizadores de este género.

Comienza el noticiero con la carátula de entrada en la que el nombre de Ecuador resalta sobre el fondo del escudo de armas y ubicando centrado y en la parte inferior del cuadro el nombre de "Ocaña film" entre dos cenefas decorativas, para a continuación iniciar la primera parte con el rótulo "La posesión del mando de S.E. el Presidente Constitucional, Dr. Isidro Ayora, ante la Hnble Asamblea Nacional 1929". Ésta y como su título indica, fundamentalmente corresponde a la toma de posesión como Presidente Constitucional por parte de la Asamblea Nacional del hasta ahora Presidente interino pero con plenos poderes-, Isidro Ayora ${ }^{3}$, designado así en su día por la segunda Junta Provisional de la denominada Revolución Juliana (Paz y Miño, 2013; Breilh y Herrera: 2011; Pérez: 2014). Mediante rótulos explicativos bilingües en español e inglés (deduzco por lo ya señalado de querer ofrecer una imagen de "pueblo civilizado" $\mathrm{y}$, tal vez, pensando en la exportación del documental), se van sucediendo diversas cortas escenas -la gran mayoría filmadas en planos generales- del evento institucional con todo el boato y la pompa propias de la época y siendo ambos, elementos necesarios por simbólicos en la legitimación de la toma del propio poder presidencial, cobrando especial relevancia la presencia del ejército durante toda la ceremonia como legitimación tanto de la propia Revolución Juliana, sostén del nuevo Estado, como del propio Presidente 


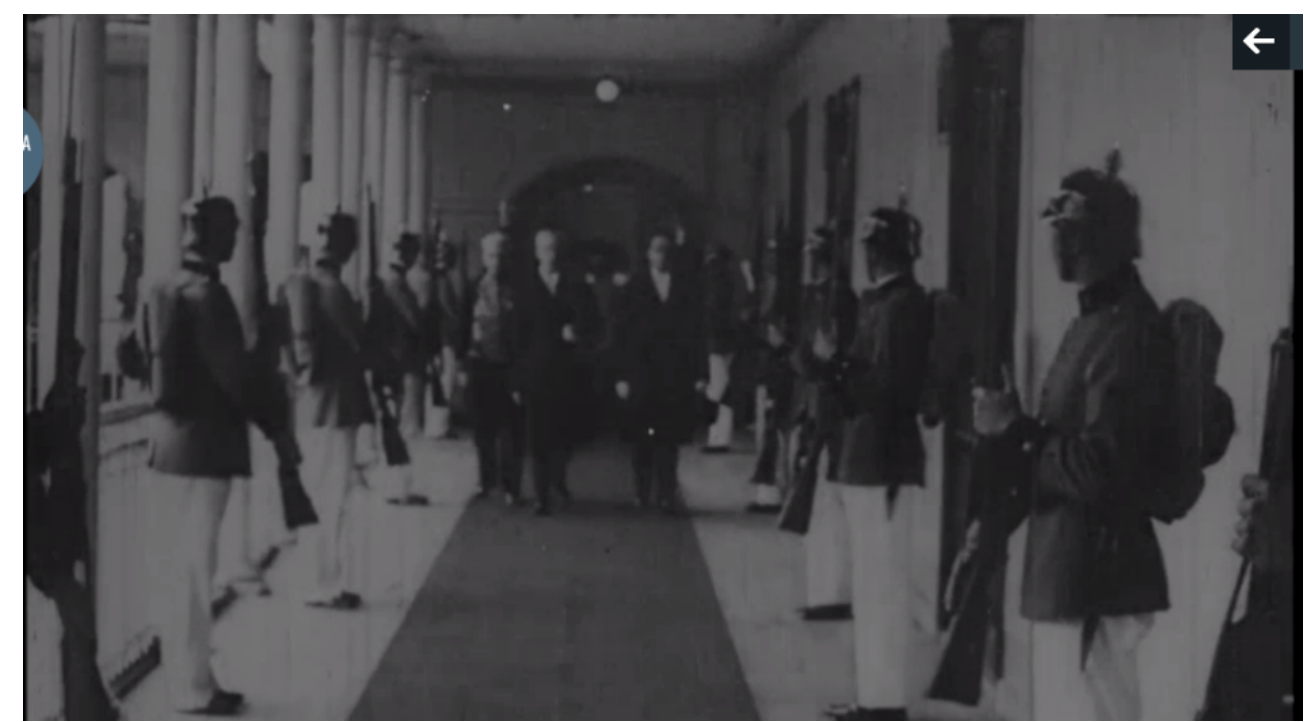

(fotograma 1).

Izquierda fotograma 1: Llegada de los Embajadores Extraordinarios al Palacio Nacional. El Embajador de los EE.UU., G.A. Bading (centro) avanzando desde la profundidad de campo del plano.

9 Tras el discurso de investidura de Ayora ante la Asamblea Nacional Constituyente con la presencia de los Embajadores Extraordinarios, prosigue esta primera parte con la intercalación de algunas cortas tomas exteriores con planos en picado diagonalizados y generales de la plaza de la Independencia rebosante de público. A continuación, ofrece el Embajador de la República de Bolivia al recién investido Presidente Constitucional un banquete de honor, rebosante de glamour y modernidad -moda "belle époque" en las mujeres- y de la más rancia tradición en los hombres que define y señala en toda su "puesta en escena" (fotograma 2), una clara y elitista distinción de la clase social que conforma y constituye la restringida cúpula del poder institucional ${ }^{4}$.

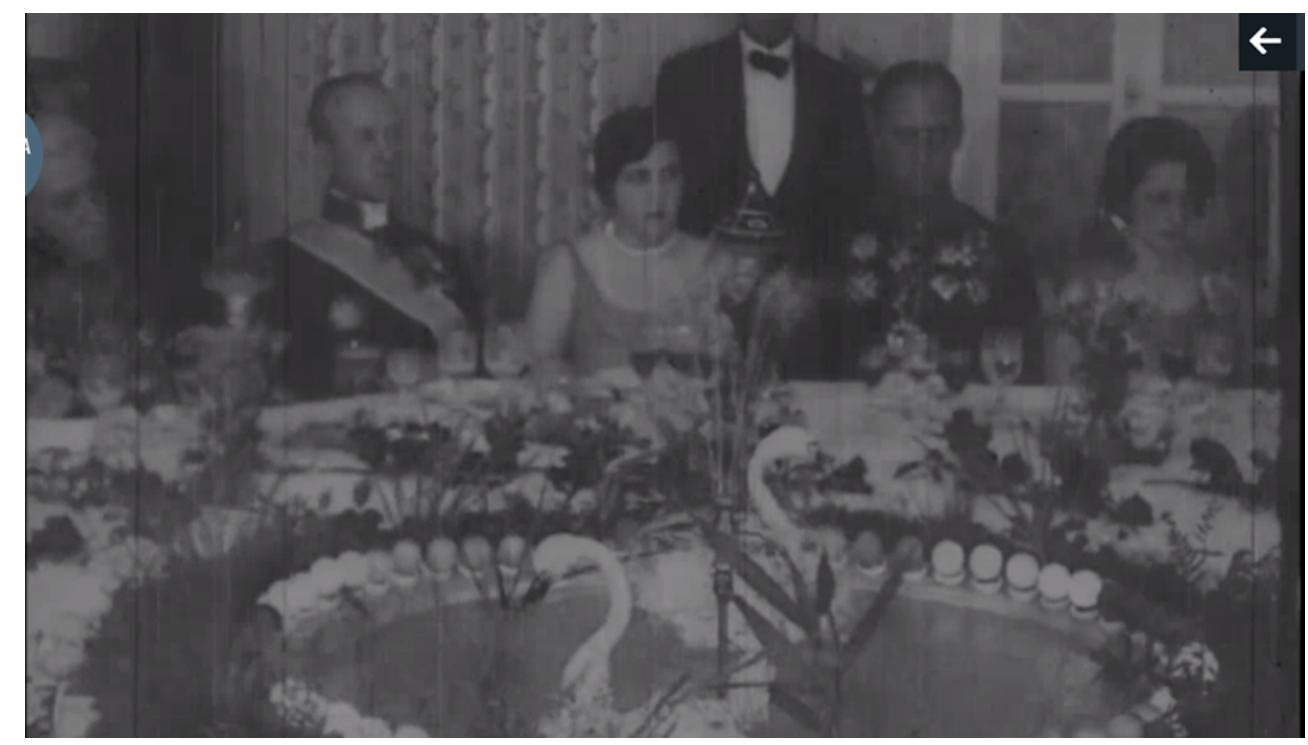

Derecha fotograma 2: Banquete de gala en honor de la investidura del Presidente Isidro Ayora con fuente iluminada en el centro de la mesa. 


\section{El Ecuador Noticiero Ocaña Film 1929 (Segunda parte y epílogo)}

10 Tal y como señalaba en A modo de prólogo, la segunda parte de este Noticiero corresponde y nos muestra la aplicación de una determinada biopolítica como símbolo de modernidad mediante, principalmente, la escolarización en diversos grados y según edades de niños y jóvenes de Quito, basada en la concepción higienista tan en boga en los años veinte y la siguiente década, tanto en el propio continente americano como en muchos países europeos. No obstante, antes de proceder al análisis de algunas imágenes seleccionadas por obvias razones de espacio y correspondientes a esta segunda parte, considero importante al respecto poder ofrecer algunas precisiones sobre la cuestión anteriormente apuntada.

11 En la cronológicamente anterior Revolución Liberal, unos de los aspectos y/o reformas más importantes a la vez que controversial de la misma, fue sin duda la progresiva implantación de una enseñanza laica, gratuita, generalizada y de calidad con nuevos sistemas pedagógicos como, por ejemplo, el en boga herbatismo aportado por las dos Misiones Pedagógicas alemanas que arribaron al país (1914 y 1922) (Herbart [1806], 1946; Gómez et alt., 1993; Sinardet, 1999; Paladines, 1990: 373-402; Paladines, 2006: 189-215; Paladines, 2018: 255-279; Uzcátegui, 1981: 85-125; Vargas, 1965: 359-408). Dicha reforma escolar, muy lenta al principio por falta de financiación, al tiempo que de una adecuada preparación de los propios maestros, tuvo su principal impulso -no sin dificultades importantes- con la fundación y ulterior desarrollo de las denominadas Escuelas Normales donde se formaron los nuevos maestros y maestras en los -en su época- revolucionarios sistemas pedagógicos ${ }^{5}$. Ahora y en el nuevo contexto de la Revolución Juliana, las reformas para la racionalización de la economía y las finanzas, la institucionalización del Estado, las acaecidas en el propio marco de las relaciones laborales (leyes ad hoc, creación de sindicatos o agrupaciones obreras, etc.) o político (por ejemplo, en 1926 se funda el Partido Socialista Ecuatoriano) (Páez, 2001: 105-154; Melgar, 2015: 2015: 24-64), la aplicación de determinados descubrimientos tecnocientíficos para la modernización de la sociedad (en medicina, urbanismo, confort, etc.), es decir, la puesta en marcha del nuevo proyecto blanco-mestizo de nación que integrase a los segmentos medios y bajos de la población, demandaba y entre otras cuestiones, la asunción de una nueva planificación educativa y pedagógica que formase a los futuros ciudadanos/as en los valores de la modernidad y el progreso (civilización). Así, la escuela estaba llamada a cumplir un rol determinante tanto en esa transformación nacional como y no más importante, en una (nueva) cultura nacional que fuese espejo de reconocimiento e identidad -homogeneizante por supuesto- de/ para todas las clases sociales, ya que, se entendía, para llevar a cabo el programa civilizatorio que las nuevas élites imponían, la nación solo podía ser una.

En relación a lo antedicho, por primera vez en la historia de la República, tanto la infancia como las mujeres fueron objeto de interés y atención por parte de los gobiernos (Goetschel, 2007), ya que debido a las altas tasas de mortalidad infantil por un lado (generación de recambio en la reproductibilidad biológica) (Clark, 1995: 184-210) ${ }^{6}$, como a la necesidad de educar a las propias mujeres en el "cuidado de si" y de sus hijos a través de conocimientos científicos (puericultura) con vistas al mejoramiento de la raza ecuatoriana ${ }^{7}$, se valoraba como indispensable la implementación de una biopolítica estatal mediante programas de enseñanza, 
asignaturas específicas y prácticas escolares para tal finalidad (higiene, gimnasia, actividades deportivas, etc.). En definitiva, se trataba de crear un nuevo habitus ${ }^{8}$ disciplinario y de obediencia en los/as futuros/as ciudadanos/as a partir ya de la enseñanza primaria para moldear un cuerpo que fuese socialmente productivo, es decir, que se adecuase en relación a las nuevas necesidades y, en consecuencia, estrategias de la economía (capitalista). Así mismo, la incorporación de las mujeres a la educación o a la enseñanza profesional venía dada tanto por preservar la "salud pública", como por las necesidades del propio sistema productivo en el reclutamiento de mano de obra cualificada sobre todo en sectores públicos como sanidad, comunicaciones o enseñanza, o en los nuevos sectores fabriles manufactureros.

Para llevar a cabo esta nueva pedagogía disciplinaria y de control sobre los cuerpos, se construirán diversas escuelas primarias y secundarias -o nocturnas para mujeres trabajadoras-, y se creará en 1926 y en Quito, la Oficina de Higiene Escolar en la que y entre otras actividades, será la encargada de llevar a cabo un registro sanitario del alumnado (características físico-antropométricas, enfermedades padecidas, salud dental, etc.) y elaborar estadísticas sanitarias (Goetschel, 2007: 125). En definitiva, todas aquellas cuestiones relativas o que afectaban a la "salud pública" (higiene y salubridad, conocimientos de puericultura, prostitución y enfermedades venéreas, mortalidad infantil, alcoholismo, etc.), lo eran y repercutían igualmente en el proyecto de la nueva nación, incluyente, moderna y civilizada (Rodas, edit., 2012) ${ }^{10}$. También resulta importante a este respecto, siquiera señalar el Congreso de Educación Primaria y Normal del Ecuador celebrado en Quito en mayo de 1930 por encargo del gobierno de Isidro Ayora y bajo la presidencia del, en la época, reconocido pedagogo Dr. Leónidas García, con la finalidad de debatir diversas propuestas pedagógicas con vistas a una reforma de la Educación Primaria y Normal. Y entre esas propuestas cabe destacar los métodos de enseñanza que la denominada "Escuela Nueva" o "Activa" propugnaba, al igual que el propio Leónidas García pues, aquellos incidían directamente en la regeneración de la raza ecuatoriana (Fernández, 2006: 77-96). Finalmente, señalar que un año antes (1929) se había creado la Facultad de Pedagogía en el seno de la Universidad Central del Ecuador en Quito y con la finalidad de formar a los futuros maestros/as de enseñanza secundaria (de la primaria se encargarían las Escuelas Normales), al tiempo que elevaba al rango de "ciencia" a la pedagogía (Sinardet, 2000: 63-107) ${ }^{11}$, muestra inequívoca de la importancia que para el Estado tenía la enseñanza científica (biopolítica) en la formación de los futuros ciudadanos.

Como señalaba al comienzo de este apartado, la segunda parte del Noticiero está dedicada casi íntegramente a mostrar los nuevos centros educativos donde se aplican esos conceptos biopolíticos, así como diversas prácticas pedagógico-educativas relacionadas con aquellos. Así pues y tras las secuencias correspondientes a la toma de posesión de Isidro Ayora como Presidente Constitucional y las consiguientes celebraciones, comienza esta segunda parte -estamos en el minuto 8 y 28 segundos- con un rótulo en el que se lee "Actividades escolares filmadas en las escuelas de Quito", para a continuación, la presencia de otro rótulo nos indica que estamos en la "Escuela de Niñas "Isabel La Católica". Desayuno escolar" (Sinardet, 1998, pp. 1441-1457) ${ }^{12}$, y en el siguiente y tercero se lee "El placer de almorzar" para mostrarnos en un corto primer plano general a un grupo de alumnas de secundaria -a juzgar por la edad-, entrando en un soleado comedor para disponerse a almorzar en varias mesas puestas en ordenada fila y adornadas todas ellas con flores. En el segundo y último plano de las mismas características, vemos a las alumnas en animada charla almorzando bajo la supervisión 
de sus maestras (fotograma 3). A destacar el encuadre diagonalizado y ligeramente elevado que realiza Ocaña y que le permite crear una perspectiva en profundidad de campo del local, para poder mostrarnos así con mayor amplitud la escena desarrollada en el comedor.

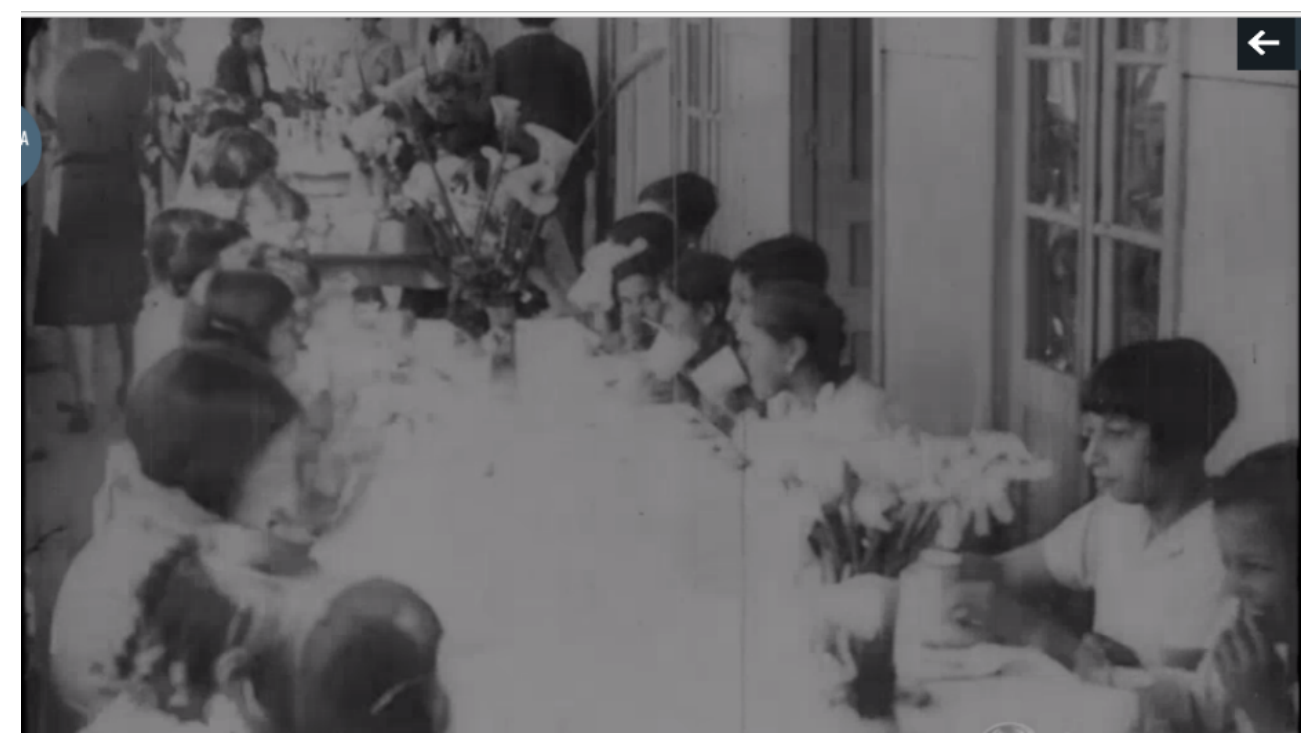

Derecha fotograma 3: Luz, espacio ventilado, flores y nutrición sana: cuerpos sanos para la raza nacional.

El desayuno escolar fue implementado con una cierta precariedad al principio (722 niños en Quito), aunque progresivamente fue extendiéndose hasta llegar a la cifra de 11.048 niños en 1931; dos años más tarde alcanzaba a todo el país exceptuando a la provincia de Esmeraldas (Goetschel, 2007: 148, Nota 29). Señalar así mismo que esta escuela tenía una piscina como forma -obligatoria- de implementar un baño semanal para todas las alumnas de acuerdo a los preceptos higienistas, además de las periódicas revisiones higiénico-médicas.

El siguiente fotograma y según se lee en el rótulo, corresponde a la "Escuela de Niños "Chile". Trabajo de taller. Sección de Madera y Cartonaje". En tres cortos planos frontales (general, americano y general respectivamente), vemos a niños y jóvenes correctamente uniformados y bajo la atención de sus maestros, laborar en un taller aprendiendo un oficio relacionado con el propio título de la Sección. Dicho oficio estaba reservado para niños exclusivamente, ya que las niñas aprendían otros de tipo "de servicio" (puericultura, enfermería, cosido y bordado, etc.) en función de su "condición" de mujer, según la mentalidad de la época. Así, el referido a la manipulación de la madera (carpintería, fabricación de juguetes) o cartonaje (embalaje) era considerado como rudo y, por tanto, masculino. En definitiva, se trataba de enseñar un oficio que facilitase la inserción laboral en el sentido de aceptación de su lugar en la división del trabajo (clase social), al tiempo que contribuyese con ese trabajo a la construcción útil de la Nación. 


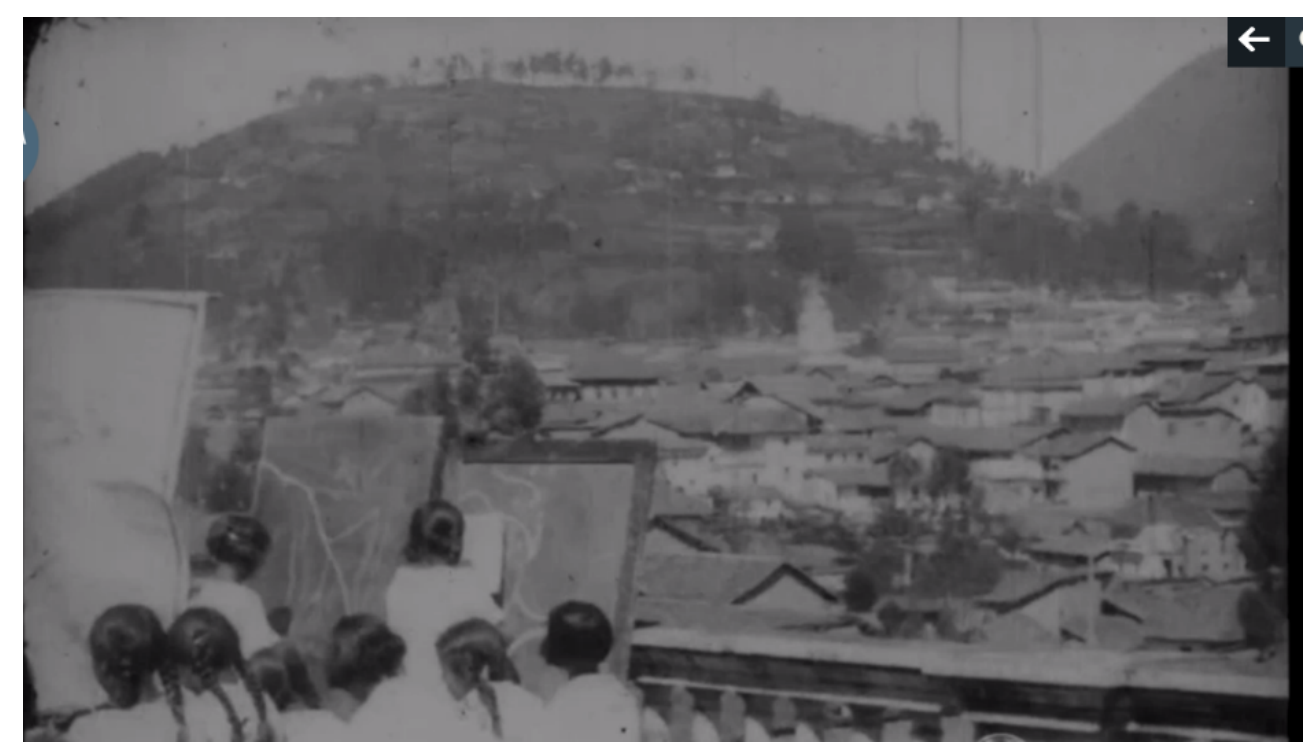

En "Escuela de Niñas "Mercedes González". Estudiando el suelo natal", mediante un único plano frontal que comienza siendo panorámico y se desplaza en barrido lateral de derecha a izquierda para finalizar deteniéndose al entrar en cuadro -extremo izquierdo- un grupo de niñas que están dibujando esa panorámica urbana en varios enormes pizarrones, además de suponer una de las herramientas didácticas correspondiente a la nueva pedagogía de la "Escuela Activa" o "Escuela Nueva", a saber, impartición de clases prácticas al aire libre y en el propio entorno a que ha lugar ${ }^{13}$, también supone unas connotaciones nacionales y patrióticas evidentes pues, ese estudio del suelo natal implicaba no solo cuestiones geográficas o urbanísticas, sino históricas y simbólicas, es decir, de construcción (imaginaria) de un relato de lo nacional en función y a partir de lo inmediato, de lo local (fotograma 4).

Izquierda fotograma 4: Al aire libre; de lo local a lo Nacional.

17 Niñas atentas, disciplinadas y homogeneizadas en esos similares peinados, en esos iguales uniformes, en esa concentración compartida por la enseñanza de lo que les es propio; niñas socializadas en una identidad única, la de la Nación ${ }^{14}$.

18 En la siguiente "Escuela "Espejo" de Niños. Se estudia y se juega" y en sus dos primeros planos, se muestra un gran y espacioso patio soleado con plantas y flores, repleto de niños y niñas muy pequeños perfectamente uniformados y agrupados/sentados ordenadamente alrededor de mesitas, y jugando y aprendiendo con juegos didácticos bajo la supervisión de sus maestras. Resulta remarcable a propósito de esta escuela y época que, por primera vez en la historia de la educación ecuatoriana, se instituye -no sin agria polémica- la no segregación en escuelas distintas de los/as niños/as por cuestiones de género.

19 A continuación y en el tercer plano, vemos en otro patio igualmente soleado, a unos niños de primaria haciendo gimnasia en perfecta formación y uniformados y mirando subrepticiamente a la cámara que los filma, mientras su instructor recorre la formación atento a la evolución y corrección de las posturas de los jóvenes (fotograma 5); es decir, disciplinando el cuerpo de las futuras generaciones para la (sana) raza ecuatoriana, y disciplinando la voluntad de los futuros ciudadanos para la (unida y homogénea) Nación. 


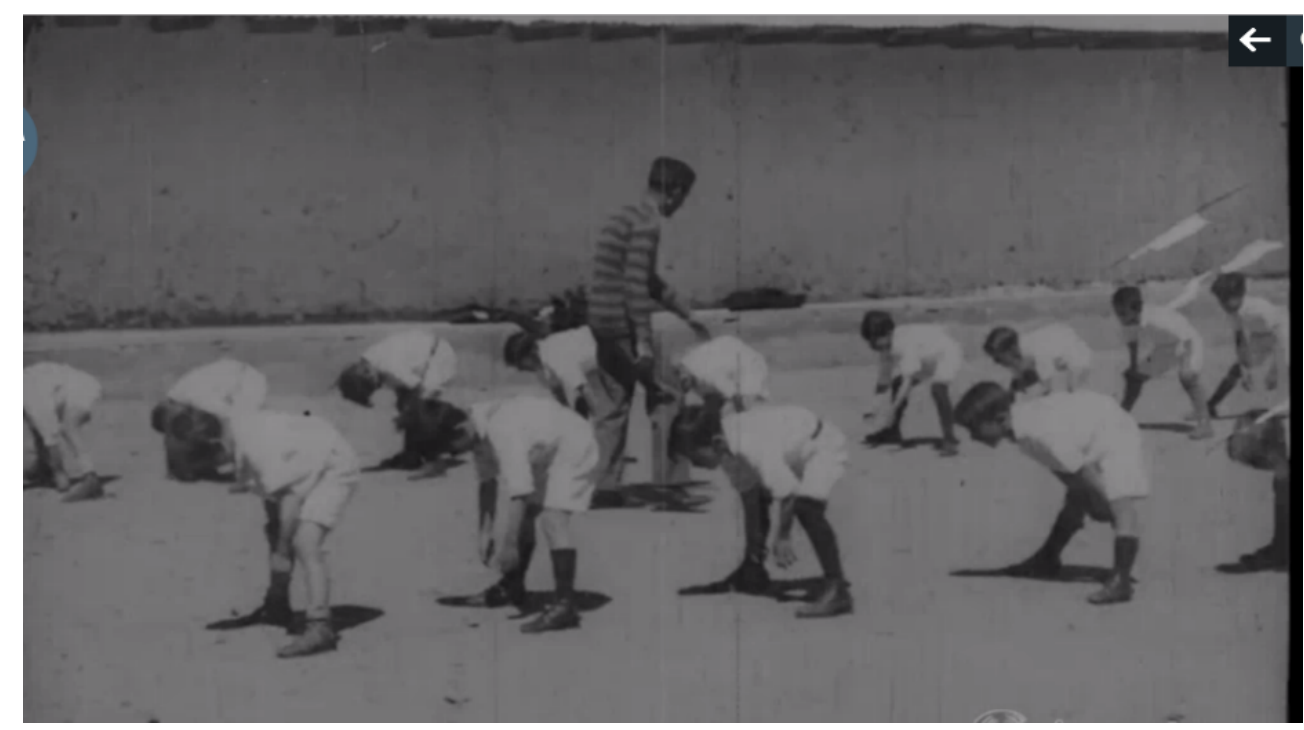

Fotograma 5: Disciplina corporal para la raza, disciplina moral para la Nación.

La siguiente filmación corresponde al "Jardín de Infantes (Escuela mixta). Aprovechando el sol de una hermosa mañana" y consta de cuatro planos de los que dos -tercero y cuartose aprecia a varios niños lavándose las manos en perfecta formación (fotograma 6), es decir, la necesidad de ejercer una pedagogía de la higiene a los niños en el contexto de una disciplina ordenancista.

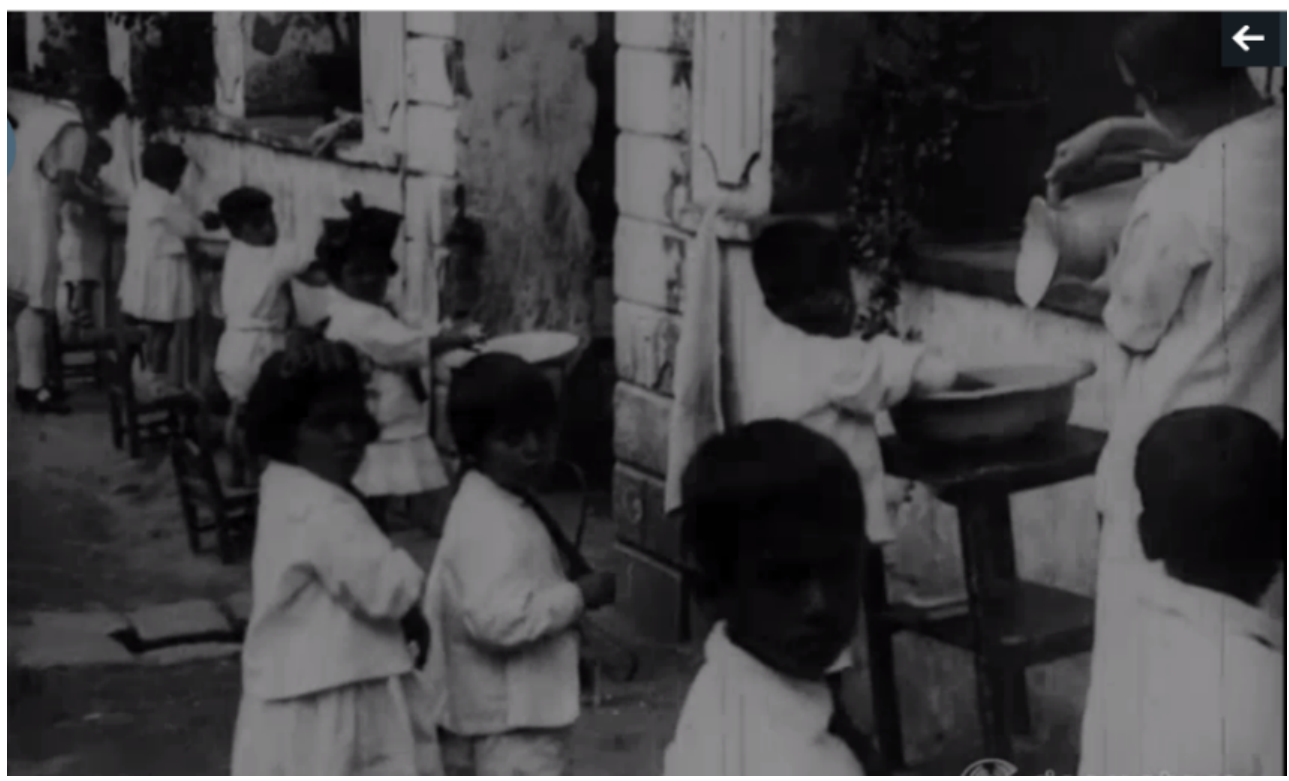

Derecha fotograma 6: La disciplinada enseñanza de la higiene.

La siguiente proyección se inicia con dos rótulos seguidos; en el primero se lee, "Asilo "Antonio Gil" (Escuela mixta). La tierra y el trabajo producen", para y a continuación en el segundo, "El trabajo agrícola dará la base de la riqueza y de la felicidad". El primer plano (general) de los dos de que se compone esta proyección, nos muestra a varios niños y niñas uniformados siguiendo atentos las indicaciones de una instructora e instructor en medio de lo que parece un huerto de cultivo. El siguiente plano (medio), muestra a un niño leyendo un libro. Como se ha señalado en casos anteriores, aquí también conviven sin segregación los/as niños/as; la novedad estriba en que al tratarse de un asilo para infantes huérfanos y/o abandonados (madres solteras pobres, prostitutas, etc.), se les 
enseña a cultivar el agro -base económica del país en aquella época-, tal y como muestra el primer plano, además de enseñarles a leer y escribir (segundo plano medio-) y de acuerdo a los fines -entre otros- de la recién promulgada Ley de Asistencia Social (1927). Así, los conocimientos adquiridos y las prácticas agrícolas llevadas a cabo en este asilo, procurarán brazos cualificados para la Nación cuando y con más edad deban abandonar dicha institución ${ }^{15}$. En definitiva, el reclamo al trabajo agrícola para la obtención de riqueza y felicidad, encubre en realidad unas relaciones de producción, tanto en el agro como en la incipiente industria, basadas en la explotación.

A continuación se muestra la "Escuela de Niños "Domingo F. Sarmiento". Un paisaje poético al servicio de la escuela", y en la que en un paisaje idílico, prácticamente selvático, varios adolescentes perfectamente uniformados, están dispersos por esa floresta leyendo. Este feraz entorno natural en que se desarrolla la enseñanza de esa escuela, nos remite a los postulados de la Escuela Nueva y del higienismo que ponderan las actividades escolares al aire libre por sus beneficios en el cuerpo y la mente. Así y nuevamente, la regeneración de la raza ecuatoriana debe basarse -entre otras- por realizar las actividades escolares al aire libre.

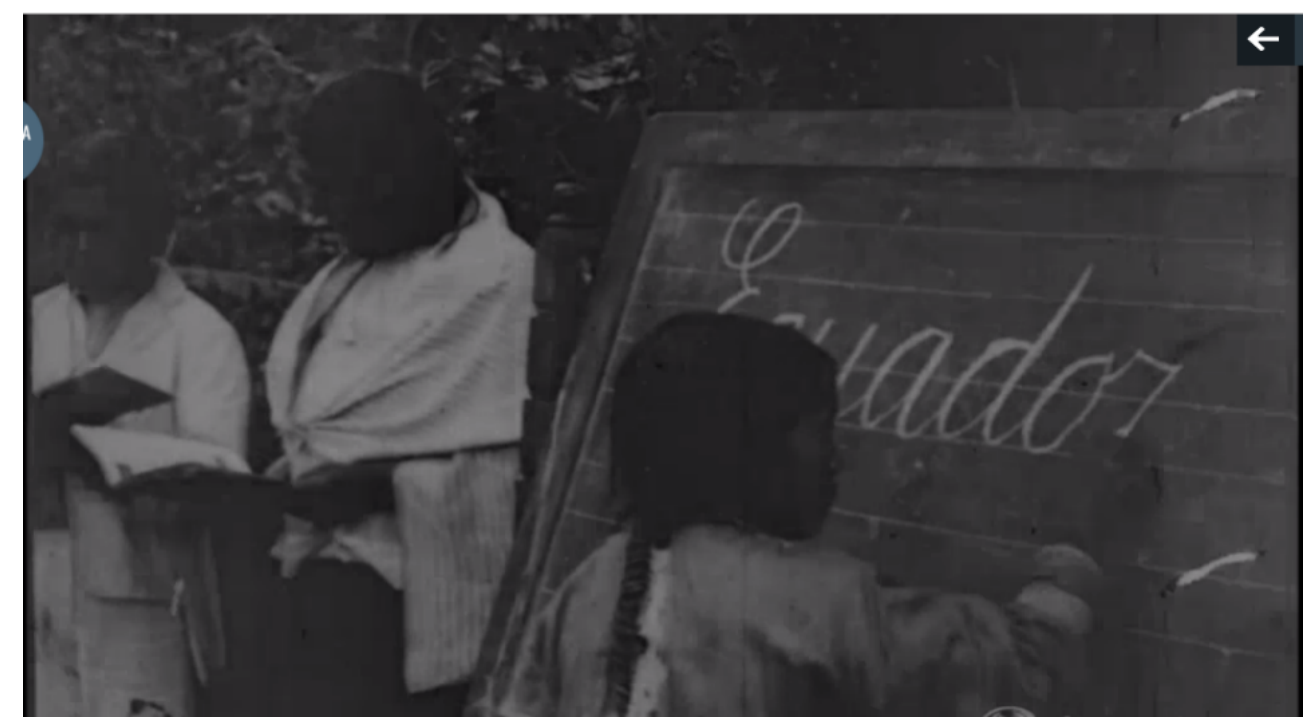

La proyección siguiente y correspondiente a la "Escuela Rural de "El Inca". También la raza indígena se educa", supone toda una declaración de principios respecto a la política integracionista para con los indígenas por parte del gobierno de Ayora. Efectivamente, en dos cortos planos pero completamente elocuentes por su contenido, se muestra una escuela rural para indígenas. Tras el primero en que se muestra el "aula" al aire libre, en el siguiente plano se observa como una niña está escribiendo, sirviéndose pacientemente de las propias guías trazadas en el pizarrón, la palabra "Ecuador" (fotograma 7).

Izquierda fotograma 7: La nación como imaginario homogeneizador de la diversidad y la patria como invención identitaria común.

23 Si en los rótulos de inicio se hacía mención al término de "Escuela Rural", conviene precisar al respecto que es en esta época cuando se inauguran este tipo de escuelas con la finalidad de incorporar a la Nación a las comunidades indígenas, mayormente habitantes en las zonas rurales.

En realidad, ese proceso de incorporación (Sinardet, 2007: 1-18) ${ }^{16}$ llevado a cabo desde los inicios de la Revolución Juliana y con mayor énfasis a partir del gobierno de Isidro 
Ayora, cabría calificarlo como de aculturación pues de lo que sintéticamente y en la práctica se trataba, especialmente en los niños y jóvenes generaciones como es el caso que aquí se muestra, era de enseñarles los valores (idioma, formas de vida, instituciones, leyes, etc.) correspondientes a la visión exclusiva, uniformadora y homogeneizante $-\mathrm{y}$, por tanto, excluyente de otras opciones- que sobre la Nación profesaban y ponderaban las nuevas élites republicanas. En definitiva, se pasó de una secular invisibilización de los pueblos indígenas a su forzosa incorporación en la hegemónica y clasista modernidad, es decir, en la civilización ${ }^{17}$. Y es que tradicionalmente los adjetivos y epítetos con que eran nombrados los indígenas, no dejaban lugar a dudas sobre su (supuesta) condición: indolente, ocioso, desaseado, de mentalidad inferior, vago, vengativo, "raza vencida", salvaje, bárbaro y un largo etcétera.

En definitiva, se consideraba que la "raza indígena" impedía, dada su idiosincrasia, el avance en la construcción de esa civilidad y progreso que las élites perseguían, y por ello, era necesario el cambio de sus costumbres y valores mediante la educación cívica y la enseñanza práctica e higienista para incorporarlos al proyecto de Nación ecuatoriana ${ }^{18}$, es decir y conclusivamente, en una biopolítica de la administración social de las poblaciones (Foucault, 2007).

Tras la antedicha, la siguiente proyección se inicia y como es habitual con un rótulo en el que se lee "La Cruz Roja al servicio de la paz". Esta consta de dos planos; en el primero, general y frontal, se ve en un local cerrado a un numeroso grupo de muy jóvenes voluntarias de la Cruz Roja Ecuatoriana, que con el mismo e impoluto uniforme y sentadas, miran a la cámara. En el siguiente y cortísimo último plano -medio-, se aprecia de perfil (en "efigie") ${ }^{19}$ a la responsable del grupo (véase la banda que porta, remedo de grado militar) y, en el que se puede en parte apreciar el escudo bordado sobre la bandera. En este se distinguen palabras como "católica", "trabajo" -en el centro y como lema-, una fecha: “... mayo 1920”, es decir, deduzco correspondiente a algún centro educativo. En definitiva, estos dos planos nos muestran a un remedo de la disciplina militar (cuartel) en una institución civil (Cruz Roja) que, además, es exclusivamente femenina (trabajo/servicio "de cuidar"). Al tiempo y en el orden institucional, el contar con una sección de la Cruz Roja en el país, suponía para el Estado-nación un importante rasgo de modernidad, conectando así con las naciones civilizadas del planeta.

A continuación, la siguiente "actualidad" comienza con el obligado rótulo explicativo; en él se lee "Niñas del Colegio "10 de Agosto", saliendo de paseo a la Alameda, en busca del campo y de la alegría". Tras la caminata por el paseo burgués por excelencia de esa época en Quito: la Alameda (Campos, 2007), a continuación y en diversos planos también generales, vemos a las mismas (?) alumnas en perfecta formación y uniforme ad hoc, realizando ejercicios gimnásticos bajo la atenta dirección de una instructora o en desfile y en inequívoca formación militar, mientras al fondo del plano vemos una muy numerosa banda militar de música que contempla la evolución de los ejercicios y marchas de las gimnastas, al tiempo que algunos de aquellos parecen tocar sus instrumentos (Fotograma 8). 


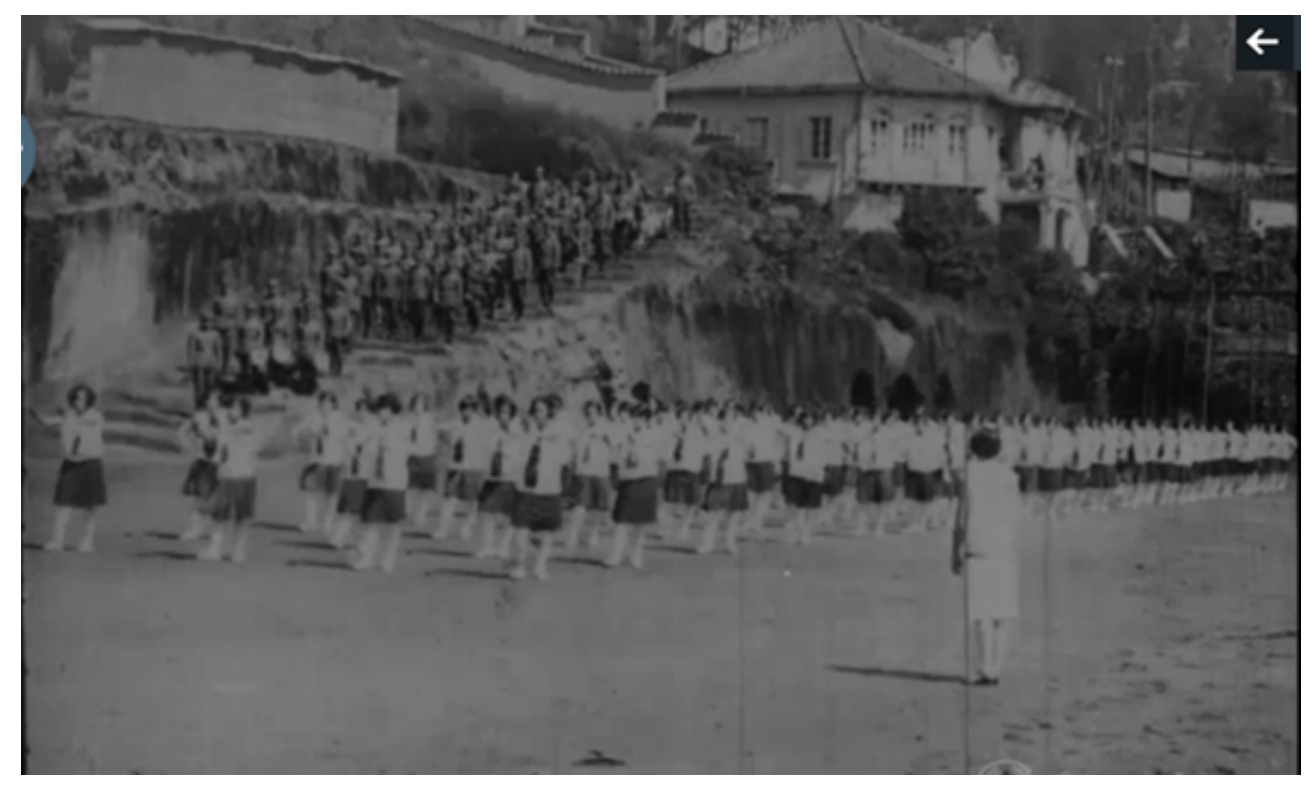

Fotograma 8: Orden militar arriba, disciplina civil abajo; una misma biopolítica ${ }^{20}$.

En los siguientes planos generales y en perfecta formación, aparecen jóvenes de ambos sexos y en posiciones interrelacionadas realizando a su vez ejercicios de gimnasia en una gran campa (fotograma 9); en otro, solo ellos y desfilando uniformemente al "paso de la oca" por la misma campa son los protagonistas, comandados por un instructor. Nuevamente y en los planos que prosiguen, aparecen las jóvenes desfilando (marcando el paso) y/o realizando ejercicios gimnásticos bajo la mirada de la banda militar de música señalada. Finalmente, aparecen en los dos últimos planos -también generales-, las jóvenes del primer plano de este reportaje, ahora en plena floresta de la Alameda poniendo así fin a la "actualidad".

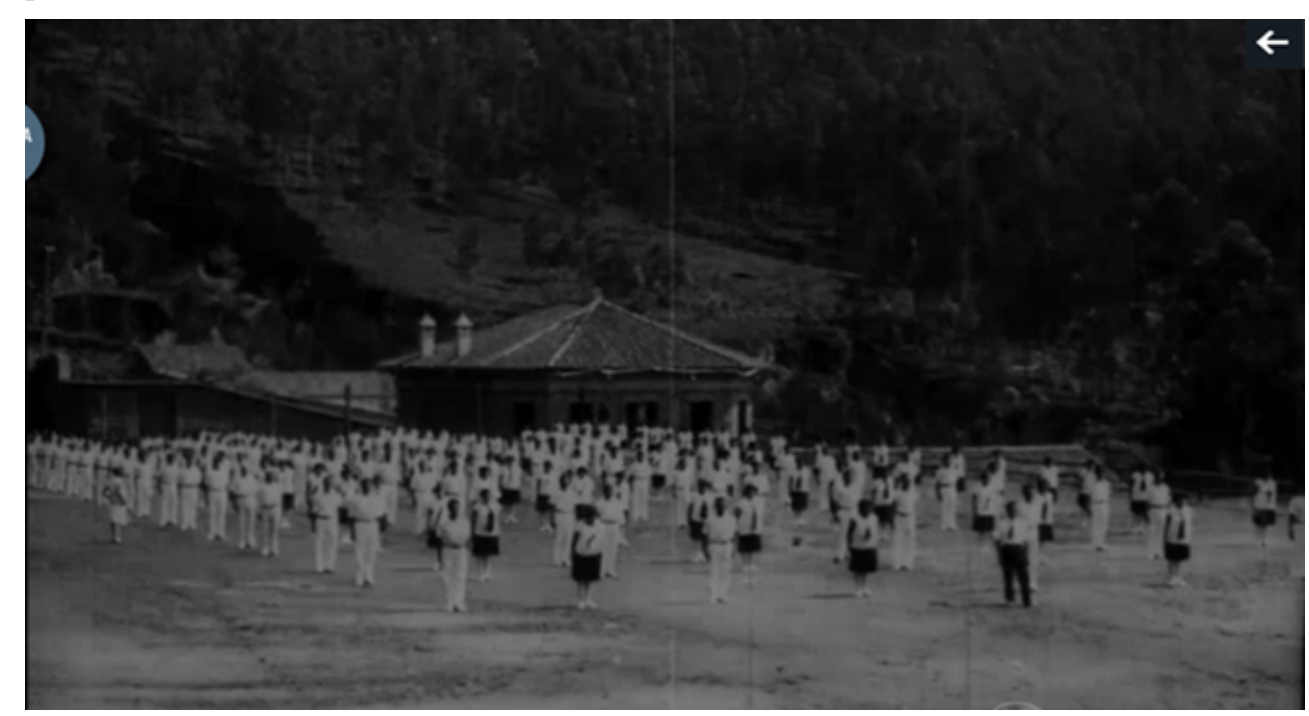

Izquierda fotograma 9: Cuerpos sanos para la nación, cuerpos disciplinados para la producción (y la reproducción).

Esta somera descripción de los planos que conforman esta parte del Noticiero, ameritan su análisis. Efectivamente, en principio y "argumentalmente", el montaje de los planos resulta un tanto anacrónico ya que, y como se ha descrito, el paseo en la Alameda de las alumnas del colegio al que hace referencia el rótulo inicial, solo es visualizado en los 
dos últimos y cortísimos planos. Ahora bien, si prescindimos del primer plano y de los dos últimos, los restantes y diegéticamente si tienen una coherencia: la de la (necesaria) educación de la juventud -ambos sexos- en la biopolítica del higienismo para poder formar a futuros y sanos ciudadanos para el cuerpo de la nación (raza ecuatoriana) y disciplinados militarmente para el "cuerpo" productivo. Así, uniformización en la vestimenta, gimnasia en la naturaleza, y marchas en formación -y música- militar al aire libre, y todo ello bajo una disciplina y obediencia castrense, forman y conforman la homogeneización de una generación de ecuatorianos/as bajo la retórica del discurso ${ }^{21}$ de la civilización y el progreso. Aquí y como señalaba en el apartado correspondiente a la primera parte del Noticiero, la apelación a los "valores" que comporta el régimen militar (obediencia, disciplina, jerarquía, orden, sacrifico), no solo son simbólicos, sino que también evidentes; o, lo que es lo mismo, los mismos "valores" fundamentan a los dos cuerpos por excelencia del Estado-nación, su cuerpo-sostén armado y su cuerpo(re)productivo racial. Por ello, estamos ante una sociedad disciplinada y disciplinaria en la que remedando el título de la carátula del comienzo, la alegría es el resultado del sometimiento del cuerpo a la castrense disciplina (biopolítica) en el campo (metáfora de la Nación).

30 Y sobre el cuerpo reproductivo de la nación y como ya he señalado, en esta nueva etapa histórica marcada por la biopolítica higienista, tanto la educación de las futuras madres como su corolario, el cuidado de los infantes, cobran un particular interés para el Estado. En este sentido, se fomenta como un ineludible factor de progreso y cuidado de la raza para su regeneración, los estudios de puericultura (nutrición, cuidados e higiene infantil) por parte de las madres, ya que "los expertos médicos relacionaron directamente la falta del instinto maternal cientificamente formado con la mortalidad infantil" (Clark,1995: 195). $Y$ es a tenor de lo antedicho y en ese contexto que debe entenderse el rótulo con que se inicia la siguiente proyección: "MATERNIDAD. Clase práctica dada en la Maternidad a las normalistas. Perfeccionando el instinto maternal. Baño y envoltura de un niño".

31 En esta y con una meritoria economía de lenguaje narrativo, se nos muestra como bañar, secar, empolvar, vestir y pesar a un bebé. Alrededor de unos doce planos entre generales y americanos, son suficientes para mostrar una clase práctica de puericultura a unas atentas y jóvenes alumnas pulcramente uniformadas. Estas y con la mirada siempre pendiente de los gestos y recomendaciones de la instructora principal (fotograma 10), aprenden "científicamente" a ser madres para provecho propio y, a su vez, transmitir ese conocimiento a futuras generaciones. Así, ciencia (puericultura), ideología (biopolítica) y política (higienismo) se interrelacionan y aúnan al servicio de la raza y de la Nación. 


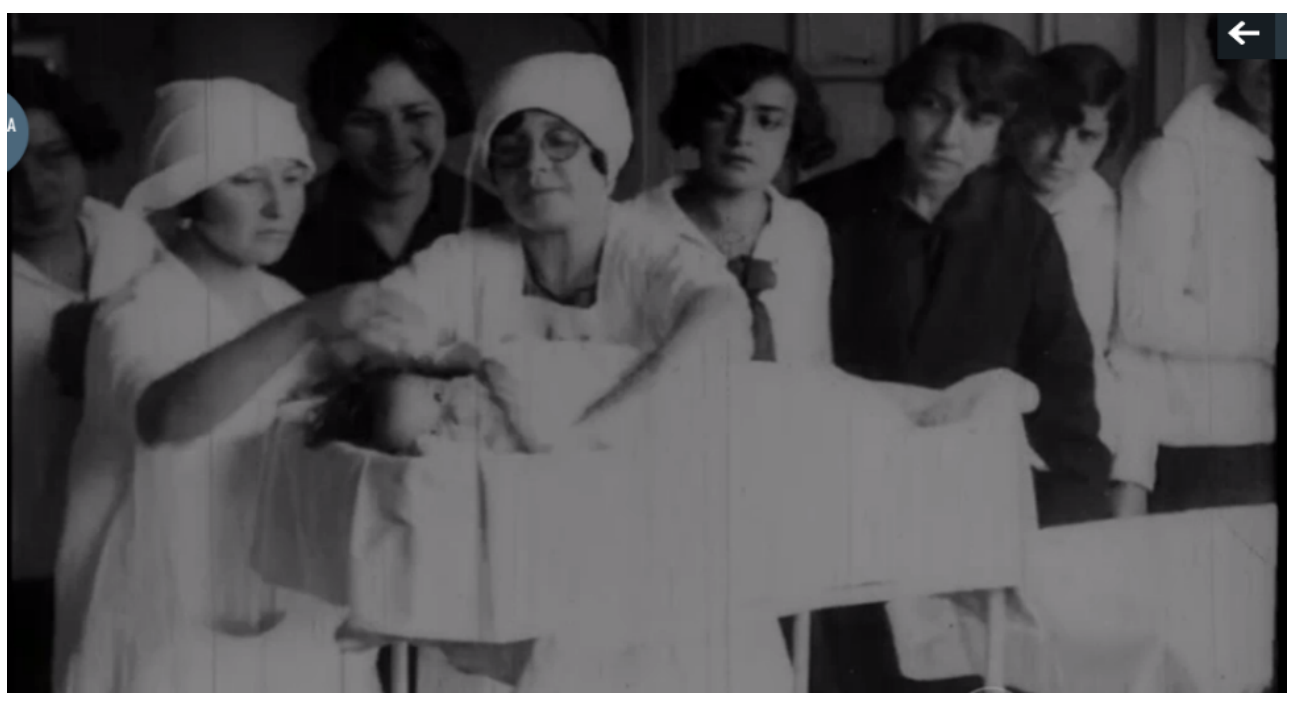

Izquierda fotograma 10: aprendiendo cuidados científicos para salvaguarda y crianza de la raza.

En la siguiente proyección y titulada "ESCUELA DE ARTES Y OFICIOS. El templo del trabajo" 22 y tras el rótulo introductorio, se nos muestra en un corto plano panorámico la fachada de entrada al gran edificio de dos plantas que alberga dicha escuela en un entorno de frondosa floresta y con claras resonancias de seminario religioso dada su tipología y formas arquitectónicas (góticas). A continuación y en el siguiente rótulo se lee "Taller de carpintería. Aprovechando la madera" o, igualmente, "Taller de mecánica. Utilizando el hierro", mostrando amplios talleres de enseñanza y trabajo con numerosos alumnos pulcramente uniformados, realizando su labor bajo la supervisión de sus profesores. Prosiguiendo, en el titulado "Taller de tejidos y cestería. Elaborando con lana y el mimbre" vemos a diversas mujeres jóvenes realizando las tareas correspondientes al título del rótulo. Al contrario que en el caso anterior, ahora se considera que este tipo de trabajo es de índole exclusivamente femenina ${ }^{23}$. E igualmente "femenino" es la enseñanza y práctica que se muestra en "Salón de dibujo. Formando a artistas".

En las dos siguientes "actualidades" y según nos explican los rótulos correspondientes, encontramos nuevamente esa constante apelación deudora de los preceptos higienistas (deporte/salud, juego/raza, higiene/agua) y cuya finalidad -ya es sabido- viene doblemente definida por el sometimiento a la disciplina ("cuerpo de la Nación") y el mejoramiento ("regeneración") de la raza ecuatoriana. Así y correlativamente vemos en primer lugar, "Piscina de Natación. jAl agua muchachos!... Patio de recreo e interior de la escuela. El juego tonifica la sangre". Y en la segunda proyección, "Colegio de niñas "24 de Mayo" en la Alameda. Alegre interior del Colegio, cuya amplitud facilita la diversión de las alumnas [larguísimo barrido lateral -de derecha a izquierda- en plano general y frontal]. También cuentan con la necesaria piscina. La buena salud se obtiene con el deporte y el agua. [Para acabar con] Frente y costado lateral del colegio "24 de Mayo". Elegancia y solidez de una escuela".

34 A continuación de lo señalado, hay un cambio en cuanto a la temática proyectada. Efectivamente, se nos muestran varios planos panorámicos y frontales en barrido lateral -de izquierda a derecha- correspondientes a tomas paisajísticas al atardecer. Después y como curiosidad novedosa para la época a la par que signo de modernidad en concordancia con las naciones "avanzadas" occidentales, en cuatro planos generales y frontales vemos a un hidroavión posado en el agua ${ }^{24}$, para y seguidamente, presenciar 
una parada militar de gala en lo que parece ser un campo de maniobras, precedida por una carroza de época (¿Presidente Ayora?) a la que todos los presentes -militares y civiles- saludan. Tropas pertenecientes a diversas clases de regimientos (ciclistas, artillería, infantería, etc.) con sus implementos de combate, desfilan marcialmente y saludan en dirección al palco presidencial y del que no vemos a sus integrantes, puesto que la cámara se halla ubicada más arriba del mismo. Así y nuevamente, el estamento militar como sostén y garante del Estado, vuelve a hacer un contundente acto de presencia.

Todas las tomas posteriores y hasta el final del Noticiero, corresponderían al epílogo que señalaba al inicio de este apartado. En estas, cobra absoluta relevancia todo lo relativo a lo agro-pecuario como enseñanza y como fuente de conocimiento $\mathrm{y}$, por tanto, de progreso para el país, al tiempo que las jóvenes generaciones y sus instructores serán sus protagonistas. Es decir, significan una clara apelación a la necesidad de aunar ciencia, técnica y trabajo en esa juventud como promesa de un futuro de progreso para la Nación.

Así, se muestra como un ejemplo de modernidad productiva (higiénica, científica y disciplinada), la "ESTACIÓN EXPERIMENTAL AGRO-PECUARIA" (1928) -fotograma 11- en la que se visualizará de una manera pedagógica, los diversos trabajos que se implementan en esa estación experimental (por ejemplo, de selvicultura).

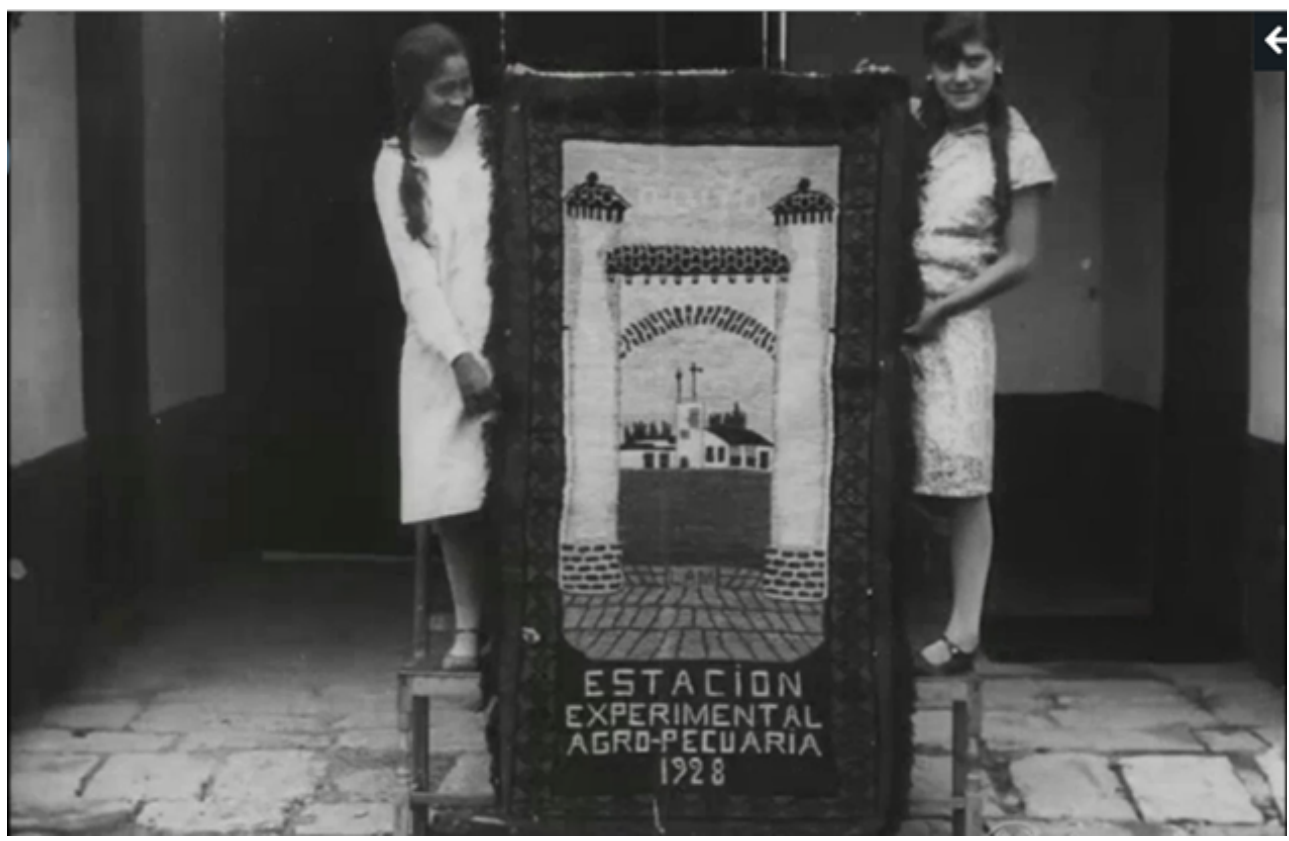

Izquierda fotograma 11: El futuro de progreso para la Nación comienza aquí.

En este complejo experimental, tanto niños como jóvenes son instruidos en los conocimientos del agro, eso sí, impecablemente vestidos para la ocasión, al igual que sus instructores, unos de uniforme y otros con camisa y corbata (?) (fotograma 12). 


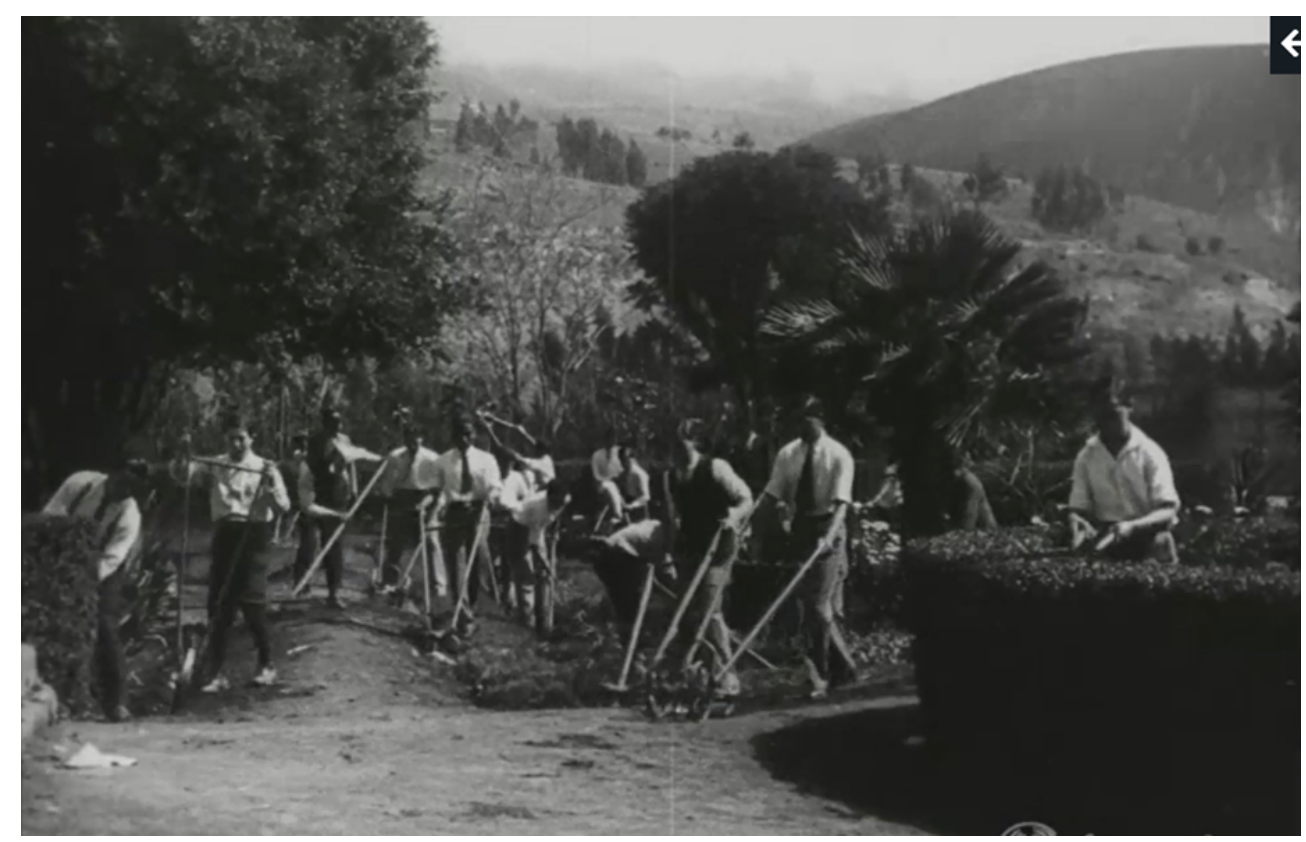

Izquierda fotograma 12: Uniformidad del trabajo, uniformidad de la vestimenta; cuerpos disciplinados para el trabajo y la Nación.

A continuación, será la "Quinta Normal de Agricultura" -fundada por Luis A. Martínez en Ambato (1903)- el objeto de presentación y en la que en ulterior plano detalle, nos mostrará técnicas agrícolas de injertos, o el propio laboratorio y el taller y, finalmente, lo pecuario. Y también como en el caso anterior, constatar que todos los instructores y/ o trabajadores que aparecen en esta última sección, están pulcramente vestidos con traje, camisa, corbata, sombrero y zapatos bien lustrados a pesar del entorno campestre en que se hallan, entiendo que para remarcar su policía como muestra del talante civilizatorio.

El último fotograma del Noticiero, obra a mi juicio de colofón simbólico de todo lo expuesto desde el inicio del mismo (fotograma 13). En aquél vemos en un plano panorámico elevado, la casa de la estación experimental junto al asta con la bandera del Ecuador engarzada, justo en la mitad de la parte izquierda del plano. Desde la profundidad de campo de la línea de horizonte, se acerca un convoy ferroviario en dirección hacia la estación, continuando su ruta en paralelo y muy cerca de la misma. Qué duda cabe que este último es símbolo por excelencia del progreso y que, al ir al "encuentro" de la estación experimental y discurrir a su vera (al igual que sus respectivas humaredas), aúna su simbolismo con el de la propia estación que es el de la ciencia (y el trabajo) en su camino hacia el progreso de la Nación (bandera nacional). Y ello, será posible con el nuevo gobierno del recién investido Presidente Constitucional, Dr. Isidro Ayora. Así y mediante el montaje de este último plano, quedan relacionadas simbólica, ideológica y políticamente las dos partes de que se compone el Ecuador Noticiero Ocaña Films 1929 de Manuel Ocaña. Se inicia así la era del progreso en el Ecuador que es, a su vez, la de las naciones civilizadas. 


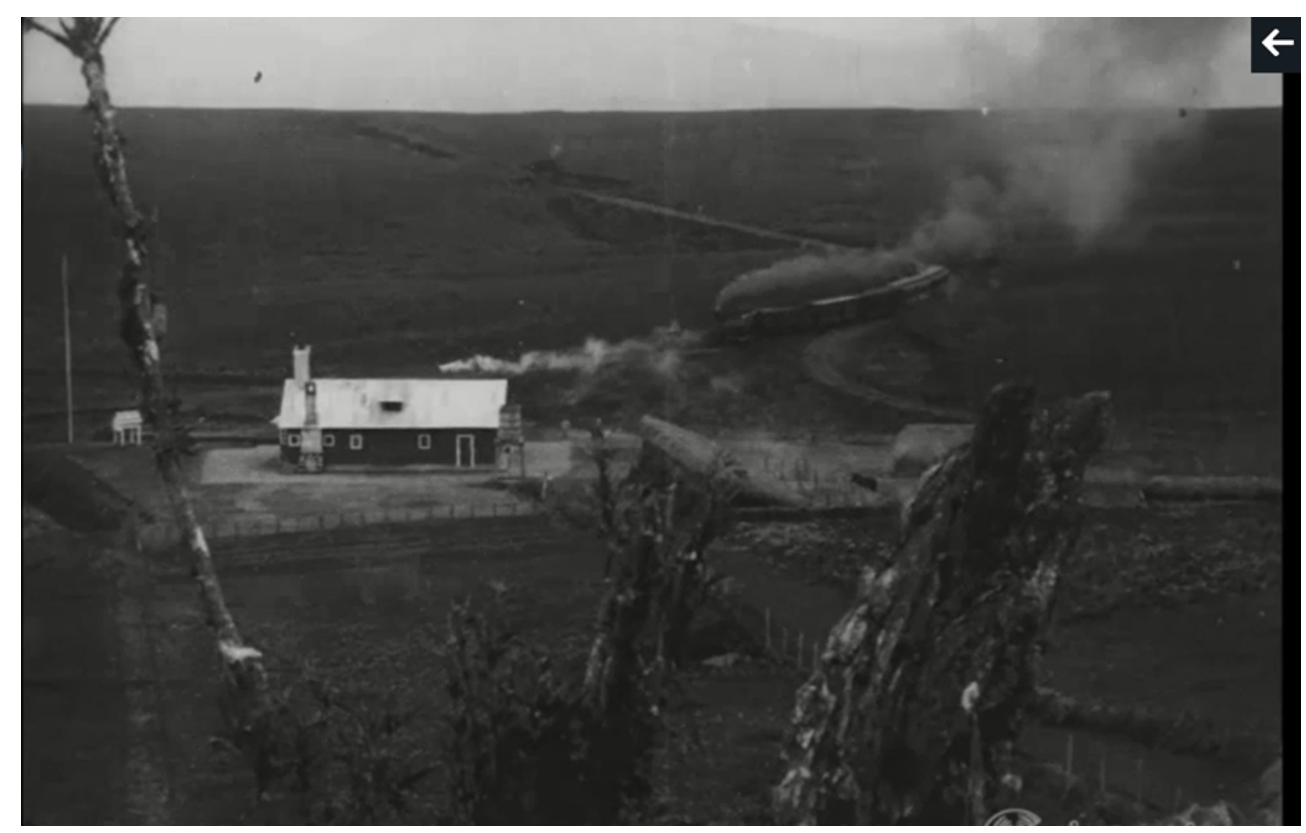

Fotograma 13: Ciencia y trabajo al servicio del progreso de la Nación.

\section{BIBLIOGRAFÍA}

ALPERIN, Tulio (2005), Historia contemporánea de América Latina, El Libro de Bolsillo, Alianza editorial, Madrid, sexta reimpresión.

ÁLVAREZ, Pocho, CORRAL, Gustavo. y SANTILLÁN, Alejandro (1989), Nosotros una historia de obreros, Documental (39'). http://cinematecanacionalcce.com/Peliculas/Detalle/3079

BOURDIEU, Pierre (1994), El sentido práctico, Taurus, Madrid.

BOURDIEU, Pierre (2002), La distinción. Criterio y bases sociales del gusto, Taurus; México.

BREILH, Jaime y HERRERA, Fanny (2011), El proceso juliano. Pensamiento, utopía y militares solidarios, Universidad Andina Simón Bolívar, Sede Ecuador-Corporación Editora Nacional, Colección Temas, Volumen 16, Quito.

CAMPOS, Alfonso (2007), Paseando por la Alameda, Fondo de Salvamento del Patrimonio Cultural de Quito (FONSAL), Quito.

CAPDEVIELLE, Julieta (2011), "El concepto de habitus: con Bordieu y contra Bordieu”, Anduli Revista Andaluza de Ciencias Sociales, $\mathrm{n}^{\circ}$. 10, Sevilla, pp. 31-45. (https://idus.us.es/handle/ 11441/50511;jsessionid=51DAE3966B464BA3B546A82487BC97BD)

CLARK, Kim (1995), “Género, raza y nación: La protección a la infancia en el Ecuador, 1910-1945”, en Martha Moscoso (comp.), Palabras del silencio. Las mujeres latinoamericanas y su historia, AbyaYala-UNICEF-Embajada Real de los Países Bajos, Quito, pp. 184-210. (http://www.flacso.org.ec/ docs/antgenclark.pdf) 
CLARK, Kim (2001), "El sexo y la responsabilidad en Quito: prostitución, género y Estado, 1920-1950”, ProcesoS, Revista Ecuatoriana de Historia, N 16, Corporación Editora Nacional, Quito, pp. 35-59.

CRESPI, Carlos (1926), Los invencibles Shuaras del Alto Amazonas (19'49"), http:// www.cinematecanacionalcce.com/Peliculas/Detalle/1045

CUEVA, Agustín (1987), El desarrollo del capitalismo en América Latina. Ensayo de interpretación histórica, Siglo XXI editores, México, décimo primera edición.

DELER, Jean-Paul (1994), “Transformaciones regionales y organización del espacio nacional ecuatoriano entre 1830 y 1930", en Juan Maiguashca, editor, Historia y región en el Ecuador 1830-1930, FLACSO, Sede Ecuador-CERLAC-Corporación Editora Nacional, Quito, pp. 295-353.

FERNÁNDEZ, Sonia (2006), "La escuela Activa y la cuestión social en el Ecuador: dos propuestas de reforma educativa, 1930-1940", ProcesoS, Revista Ecuatoriana de Historia 23, I semestre, Quito, pp. 77-96. http://repositorio.uasb.edu.ec/bitstream/10644/1751/1/RP-23-ES-Fern\%c3\%a1ndez.pdf FOUCAULT, Michel (1992), El orden del discurso, Tusquets Editores, Barcelona.

FOUCAULT, Michel (2007), Nacimiento de la biopolitica, Fondo de Cultura Económica, Buenos Aires. GOETSCHEL, Ana María (2007), Educación de las mujeres, maestras y esferas públicas. Quito en la primera mitad del siglo XX, FLACSO, Sede Ecuador-Abya-Yala, Quito.

GOMEZ, Jorge et alt. (1993), Las misiones pedagógicas alemanas y la educación en el Ecuador, Proyecto de Educación Bilingüe Intercultural/Ministerio de Educación y Cultura-Abya-Yala, Quito.

GRANDA, Wilma (1995), Cine silente en Ecuador (1895-1935), Casa de la Cultura EcuatorianaCinemateca Nacional-UNESCO, Quito.

HERBART, Johan Friedrich [1806] (1946), Antología de Herbart, Selección de textos y Estudio Introductorio de Lorenzo Luzuriaga, Publicaciones de la Revista de Pedagogía. Textos pedagógicos, Losada, Buenos Aires.

KINGMAN, Eduardo (2008), La ciudad y los otros. Quito 1860-1940. Higienismo, ornato y policía, FLACSOSede Ecuador-FONSAL-Universitat Rovira i Virgili, Quito.

KINGMAN, Eduardo (2010), “Cultura popular, vida cotidiana y modernidad periférica”, en Valeria Coronel y Mercedes Prieto, coordinadoras, Celebraciones centenarias y negociaciones por la nación ecuatoriana, FLACSO, Sede Ecuador-Ministerio de Cultura, Quito, pp. 123-154.

KINGMAN, Eduardo (2014), “Oficios y trajines callejeros”, en Eduardo Kingman Garcés y Blanca Muratorio, Los trajines callejeros. Memoria y vida cotidiana. Quito, siglos XIX-XX, FLACSO, Sede Ecuador-Instituto Metropolitano de Patrimonio-Fundación Museos de la Ciudad, Quito, pp. $27-112$.

LEÓN, Christian (2010), Reinventando al otro. El documental indigenista en el Ecuador, La Caracola Editores, Quito. http://repositorio.uasb.edu.ec/handle/10644/3957

LUZURIAGA, Sofía (2010), “Abastecimiento de agua y políticas de saneamiento en Quito, 1880-1930”, PROCESOS, Revista Ecuatoriana de Historia, 32, II semestre, Quito, pp. 31-56, http:// repositorio.uasb.edu.ec/bitstream/10644/2849/1/03.Luzuriaga-E.pdf

MARCHÁN, Carlos (comp.) (1988), Crisis y cambios de la economía ecuatoriana en los años veinte, Ediciones del Banco Central del Ecuador, Quito, segunda edición.

MELGAR, Ricardo (2015), "Marxismo y socialismo en el Ecuador: la cuestión de los orígenes", VIII Jornadas Historia de las Izquierdas. Marxismos Latinoamericanos. Tradiciones, debates y nuevas perspectivas desde la historia cultural e intelectual, 18, 19 y 20 de noviembre, Centro de 
Documentación e Investigación de la Cultura de Izquierdas-Universidad Nacional San Martín (CeDInCI/UNSAM), Buenos Aires, pp. 24-64. http://cedinci.unsam.edu.ar/PDF/Jornadas/ VIII\%20Jornadas.pdf y http://www.pacarinadelsur.com/home/alma-matinal/1259-marxismo-ysocialismo-en-el-ecuador-la-cuestion-de-los-origenes

NN (1927), La Escuela de Artes y Oficios de Quito, Departamento de Información anexo a la Secretaría Privada de la Presidencia, $\mathrm{N}^{\circ}$ 2, Talleres Tipográficos Nacionales, Quito.

OCAÑA, Manuel (1929), Ecuador Noticiero Ocaña Film de Manuel Ocaña (23’04'), http:// www.cinematecanacionalcce.com/Peliculas/Detalle/1013

ORTIZ, Gonzalo (1990), “Las condiciones internacionales (1875-1914)”, en Enrique Ayala Mora, Editor, Nueva Historia del Ecuador, Volumen 9, Época Republicana III, Cacao, Capitalismo y Revolución Liberal, Corporación Editora Nacional-Editorial Grijalbo Ecuatoriana Ltda., Quito, primera reimpresión.

PÁEZ, Alexei (2001), Los orígenes de la izquierda ecuatoriana, Fundación de Investigaciones Andino Amazónicas (FIAAM)-Abya Yala, Quito.

PALADINES, Carlos (1990), Sentido y trayectoria del pensamiento ecuatoriano, Biblioteca de la Revista Cultura II, Ediciones del Banco Central del Ecuador, Quito, pp. 373-402.

PALADINES, Carlos (2006), Historia de la educación y del pensamiento pedagógico ecuatorianos, Ediciones de la Universidad Técnica Particular de Loja, Loja, pp. 189-215.

PALADINES, Carlos (2018) Historia de la educación y del pensamiento pedagógico ecuatorianos, Centro de Publicaciones PUCE (Pontificia Universidad Católica del Ecuador), Quito, pp. 255-279, sexta edición.

PAZ Y MIÑO, Juan José (2000), Revolución Juliana, Nación, Ejército y Bancocracia, Abya Yala, Quito, $2^{\mathrm{a}}$ edición.

PAZ Y MIÑO, Juan José (2013), La Revolución Juliana en Ecuador (1925-1931) Políticas Económicas, Serie Historia de la Política Económica del Ecuador, Ministerio Coordinador de Política Económica. Quito.

PEREZ, Trinidad (2010), "Nace el arte moderno: espacios y definiciones en disputa (1895-1925)", en Valeria Coronel y Mercedes Prieto (coord.), Celebraciones centenarias y negociaciones por la nación ecuatoriana, FLACSO-Sede Ecuador, Quito, pp. 23-75.

PEREZ, Gustavo (2014), La Revolución Juliana y sus jóvenes líderes olvidados, Academia Nacional de Historia, Quito, segunda edición.

PRIETO, Mercedes (1980), “Haciendas estatales: un caso de ofensiva campesina: 1926-1948”, en VV.AA. Ecuador: cambios en el agro serrano, FLACSO-Sede Ecuador-CEPLAES, Quito, pp. 103-130.

PRIETO, Mercedes (2004), Liberalismo y temor: imaginando los sujetos indígenas en el Ecuador postcolonial, 1895-1950, FLACSO-Sede Ecuador-Abya Yala, Quito.

RAMÍREZ, Jacques (Ed.) (2012), Ciudad-Estado, Inmigrantes y Políticas. Ecuador, 1890-1950, Estudios Migratorios $\mathrm{N}^{\circ} 2$, Instituto de Altos Estudios Nacionales (IAEN), Quito. https:// editorial.iaen.edu.ec/wp-content/uploads/2016/06/Ciudad-Estado-inmigrantes-ypoli\%CC\%81ticas.pdf

RODAS, Germán (Ed.) (2012), Revolución juliana y salud colectiva, Universidad Andina Simón Bolívar, Sede Ecuador-Corporación Editora Nacional, Quito.

SINARDET, Emmanuelle (1998), "La mujer en el proyecto nacional de la revolución liberal ecuatoriana (1895-1925): ¿qué representación de la mujer?”, XIII Coloquio de historia canario- 
americano, Cabildo Insular de Gran Canaria, Las Palmas de Gran Canaria (España), pp. 1441-1457. http://mdc.ulpgc.es/cdm/ref/collection/coloquios/id/760

SINARDET, Emmanuelle (1999), “La pedagogía al servicio de un proyecto político: el herbatismo y el liberalismo en el Ecuador (1895-1925)”, ProcesoS, Revista Ecuatoriana de Historia, No. 13, Corporación Editora Nacional, Quito, pp. 25-41. http://repositorio.uasb.edu.ec/bitstream/ 10644/1447/1/RP-13-ES-Sinardet.pdf

SINARDET, Emmanuelle (2000), "La difficile constitution du corps enseignant équatorien: 1895-1946”, Bulletin de l'Institut français d'études andines, vol. 29, núm. 1, Institut Français d'Études Andines, Lima, pp. 63-107. http://www.redalyc.org/articulo.oa?id=12629104

SINARDET, Emmanuelle (2007), “Educación indígena y políticas de incorporación nacional (1925-1946): de la integración a la exclusión”, Revue HISTOIRE(S) de l'Amérique latine (HISAL), Volume 2, Université Paris Ouest Nanterre - La Défense, Département d'études ibériques et ibéroaméricaines, Nanterre (Francia), pp. 1-18. http://www.hisal.org/revue/article/sinardet2007-1

UZCÁTEGUI, Emilio (1981), La educación ecuatoriana en el siglo del liberalismo, Ed. Voluntad, Quito.

VARGAS, Fr. José María (1965), “La instrucción pública durante la República” en Historia de la cultura ecuatoriana, Casa de la Cultura Ecuatoriana, Quito, pp. 359-408. También disponible en http://www.cervantesvirtual.com/obra-visor/historia-de-la-cultura-ecuatoriana--0/html/ 0027fcd4-82b2-11df-acc7-002185ce6064_28.html\#I_109_

\section{NOTAS FINALES}

1. Ecuador Noticiero Ocaña Film (1929) de Manuel Ocaña (23'04'), disponible on-line en http:// www.cinematecaecuador.com/Peliculas/Detalle/1013

2. Así y por higienismo cabe entender a "una corriente médico-social que buscaba ordenar el funcionamiento del espacio social y físico a partir de criterios positivistas, como la salud y el bienestar de las poblaciones" (Kingman, 2008: 326). En función del desarrollo del presente trabajo se irá relacionando y matizando dicho concepto en su contexto histórico ecuatoriano, que es donde alcanza su real sentido a los efectos que guían al presente texto. Y el término policía viene referido "en su sentido teórico más amplio al cuidado de la ciudad" (Kingman, 2008: 344), bien entendido este de acuerdo al concepto de civilidad, es decir a los diversos usos y costumbres que practicaban las élites como las formas de cortesía, el aseo personal, el tipo de vestimenta considerada como adecuada, hábitos alimentarios saludables, etc. En definitiva y tal como el citado autor identifica, "Las oposiciones planteadas por los higienistas entre salud y enfermedad, suciedad y limpieza, se convirtieron en recursos para pensar lo social en un momento de tránsito de la ciudad señorial a la "moderna" (Kingman, 2008: 328).

3. Reconocido por las numerosas reformas modernizadoras de diverso carácter que impulsó dicho Presidente (institucionales, laborales, financieras, políticas, etc.), no obstante cabría señalar que aquellas significaron en realidad una "puesta al día" del capitalismo ecuatoriano, sin reformas estructurales que cuestionasen las propias bases de aquél, a saber, tanto la propiedad de los medios de producción como a las propias relaciones de producción; simplemente unas nuevas "reglas de juego", más racionales, funcionales y modernas y que, en la práctica, encubren y siguen perpetuando una estructura de dominación, explotación y acumulación de capital por parte de las nuevas élites. Y sobre esta crucial cuestión, conviene no olvidar que durante su mandato como Presidente interino y después constitucional, Ayora reprimió a cualquier atisbo de oposición, multando y/o cerrando periódicos (El Guante, El Día o Confederación Obrera entre otros) y enviando al exilio (Oriente, Galápagos) a muchos opositores; o la sangrienta represión en los levantamientos indígenas de Columbe y Colta en 1929, en la huelga general de los indios de las 
haciendas de Olmedo (1930-31) o, igualmente la represión en el intento del primer Congreso indígena en Cayambe (1930/1931).

4. Rompiendo una de las principales convenciones cinematográficas, en muchos de los fotogramas que integran esta secuencia, la mayoría de los personajes que aparecen en ella incluido el propio Presidente Ayora, miran sonrientes a la cámara que les filma.

5. El fundador e impulsor de las Escuelas Normales y no sin un cierto fracaso en sus inicios, fue Luis A. Martínez a la sazón primero Subsecretario de Instrucción Pública (1903) y después ministro de la misma cartera (1904-1905) en el primer gobierno de Leónidas Plaza (1901-1905). En este contexto, debe señalarse que el oficio de maestro (las maestras eran prácticamente inexistentes pues se consideraba que la mujer debía dedicarse a su hogar y familia) estaba valorado como entre lo más bajo en la escala socio-laboral, además de muy mal pagado y casi siempre con muchísimo retraso, cuestiones estas que se prolongarían unas decenas de años más.

6. "Entre 1917 y 1922, la tasa de mortalidad infantil era de 34 a 40 muertos por cien nacimientos" (Clark, 1995: 186).

7. Por "raza" y en este contexto, no debe entenderse que se refiera ideológicamente a "diferencias biológicas inalterables que solamente pudieran ser cambiadas genéticamente, sino [que debe entenderse] en términos del peligro de ciertos comportamientos que podían dañar a futuras generaciones de ecuatorianos, a través de la acción de 'venenos raciales"' y, siendo estos y fundamentalmente, las enfermedades venéreas y el alcoholismo, (Clark, 1995: 201). Otro ámbito no menos importante para mejorar la "raza ecuatoriana" fue el de las políticas inmigratorias desarrolladas ya desde finales del siglo XIX (especialmente con ciudadanos europeos), pero que alcanzaría su mayor importancia a partir de finales de los años veinte $y$, muy especialmente, a partir de la década de los años treinta con la finalidad de que pudieran contribuir a la construcción de un estado-nación de progreso y moderno, es decir, acorde con las naciones “civilizadas"; sintéticamente, dichas políticas implicarían:

“- Una eficaz política inmigratoria y de colonización permitirá alcanzar un debido desarrollo económico, cultural y étnico.

- La inmigración permitirá poblar racionalmente el país, sin mezclas exóticas, tratando de mejorar el coeficiente vital de la población ecuatoriana.

- La raza determinará el progreso de la nación, y por eso hay que impulsar una inmigración selecta de trabajadores europeos, racialmente superiores, que es la aspiración de todos los que ven el mejoramiento racial la promesa de un país superior.

- Se necesita trabajadores inmigrantes "contadinos", es decir, campesinos y agricultores con medios económicos propios a quienes el Estado tiene que ofrecer todas las facilidades" (Ramírez (Editor), 2012: 35-36).

8. Empleo el término de habitus en el sentido de Pierre Bourdieu (1994); es decir y sintéticamente, se refiere a la internalización de las estructuras sociales por la persona en forma de esquemas de percepción, pensamiento (imaginarios, moral, etc.) y, por tanto, de acción, lo que supone en la práctica, la constitución de aquella como sujeto. No obstante, dicha noción no debe ser entendida como algo estático, sino que los propios "juegos de fuerza" al interior de un "campo social" la pueden convertir en algo dinámico y cambiante (Goetschel, 2007: 21-22; Capdevielle, 2011: 31-45). 9. Efectivamente, "la prostitución representaba un serio peligro para las generaciones futuras. Las enfermedades venéreas fueron identificadas como un veneno racial, es decir, como algo que podía destruir las células germinales transmitiendo degeneración racial a las generaciones posteriores" (Clark,1995: 199; Clark, 2001: 35-59).

10. Por ejemplo y como dato a este respecto, "muchas de las capitales provinciales no contaron con los necesarios sistemas de desecho de las aguas servidas y con agua corriente hasta la década de 1940" (Clark, 2003: 128).

11. "La facultad de pedagogía debuta con 16 profesores, 168 estudiantes de los que 22 son mujeres

(...) El programa [de estudios] ultimado en 1930 incluye la filosofía, la lengua y la literatura 
castellana, la educación moral y cívica, la historia, la psicología y las ciencias biológicas, la geografía, las ciencias naturales, el francés y el inglés, el dibujo y la música" (Sinardet, 2000: 86). 12. "La integración de la niña en el sistema escolar da resultados. En los años 1928, hay 59.215 alumnas de los 128.446 escolares, o sea el $46 \%$, lo cual en el contexto de la época representa un número impresionante" (Sinardet, 1998: 1444). Conviene precisar a este respecto que a pesar de las reformas llevadas a cabo en la enseñanza durante el período liberal (1895-1925), no existían institutos de enseñanza secundaria para niñas dada la moral imperante sobre la mujer, es decir, educarla únicamente para saber leer y escribir y, principalmente y sobretodo, para ser buena ama de casa, esposa y madre, dada su "delicadeza moral y debilidad física". Será a partir del período que nos ocupa, que se creen los primeros institutos de enseñanza secundaria femenina, aunque a finales de esa década la presencia masculina en aquellos seguirá siendo mayoritaria.

13. Decir al respecto y muy sintéticamente que los nuevos métodos didácticos de la Escuela Nueva, sobretodo aplicados a la instrucción de la infancia, se basaban en la propia concepción pedagógica de aquella, a saber, una enseñanza no dogmática sino deductiva, reflexiva y no memorística, participativa y empírica y que hiciese énfasis en las cuestiones referidas al higienismo como método de regeneración social y de homogeneización nacional, al tiempo que desarrollase desde la niñez el sentido de la responsabilidad (disciplina); en síntesis, una enseñanza que potenciase el desarrollo psíquico e intelectual del niño/a, además de su fortalecimiento y bienestar biológico a través de la higiene y la gimnasia como método de rehabilitación de la "raza ecuatoriana" (desarrollo biogenético). Ver también para esta cuestión, el trabajo ya citado de Fernández (2006).

14. Creo en este punto importante precisar y como Goetschel (2007) muy acertadamente señala reiteradamente en su libro que, "El papel de la escuela debe leerse, entonces como ya lo he manifestado, en varios sentidos: como protección estatal y proceso civilizador y de control, pero también como algo que se define internamente como resultado del juego de diversas posiciones interesadas en su desarrollo (...) Se trató de un proyecto real pero también imaginado en el que entraron en juego una diversidad de intereses con posiciones contrarias, en enfrentamiento y negociación constantes" (p. 140).

15. Uno de los grandes problemas crónicos para los terratenientes, hacendados y gamonales desde la fundación de la República, fue la escasez de mano de obra agrícola, particularmente en la Sierra. E igualmente para el Estado en la realización de obras públicas (construcción de caminos y/o edificaciones, desecación de zonas pantanosas, trazados del ferrocarril, etc.), por lo que y en este último caso, se procedía a realizar levas, especialmente entre la población indígena.

16. "La integración se opone simétricamente a la exclusión mientras que la incorporación se perfila como una integración parcial ya que simultáneamente garantiza de forma sutil la reproducción de cierta exclusión" (Sinardet, 2007: 5).

17. Muy reveladores resultan los intensos debates -sobre todo de tipo jurídico y político, aunque también moral- sobre el estatuto jurídico de las comunidades indígenas y sus representantes ante la Asamblea Nacional; igualmente acerca de la propiedad colectiva o individual de las tierras donde habitaban y su usufructo (Ley de Patrimonio Territorial, 1927) o, igualmente sobre el derecho a la transmisión de la propiedad de las mismas. Debates efectuados no solo por los políticos en la Asamblea Nacional, sino también por intelectuales ilustrados de la clase media en, sobretodo, periódicos y revistas de la época. En cualquier caso, no sería hasta más tardíamente cuando muchas de estas cuestiones hallarían su reglamentación legal con, por ejemplo, la Ley de Organización y Régimen de Comunas (1937) o el propio Estatuto Jurídico de las Comunidades Campesinas, del mismo año (Prieto, 2004: 123-164). Creo importante señalar que, en general, las comunidades indígenas aceptaron las "vías institucionales" que las élites políticas legislaban sin la participación -en la inmensa mayoría de las ocasiones- de las propias comunidades. Un ejemplo ilustrativo entre otros muchos de lo antedicho, serían los trágicos sucesos acaecidos en diversas haciendas de olmedo (1930-1931), a raíz de la huelga reivindicativa de mejores condiciones de 
trabajo y salariales por parte de los trabajadores indígenas huasipungueros (Prieto, 1980: 103-130, pp. 115-117 para lo señalado).

18. Este "paternalismo" como nueva actitud de dominación y construcción de subjetividades mediante un previo proceso de aculturación, hallará su reflejo en la representación fílmicodocumental del mundo indígena, tanto la de los pueblos habitantes de la Amazonía como los de otras comunidades y geografías nacionales. En relación a lo antedicho, por ejemplo y para el primer ámbito geográfico, resulta esclarecedor el documental del salesiano Carlos Crespi, Los invencibles Shuaras del Alto Amazonas (1926). Para una diacronía analítico-crítica de las diversas formas de representación de los pueblos indígenas véase, León, 2010.

19. Simplemente recordar que, hasta época muy reciente, le representación en "efigie" en monedas, billetes, bajorrelieves o sellos postales -entre otros- de determinadas personas, estaba exclusivamente reservada para los grandes personajes (reyes, papas, generales, etc.), pues denotaba dicha forma de representación, la excelsitud de la persona representada.

20. "El cultivo de nuevas características sociales y personales a partir del ejercicio de la autoridad pedagógica, facilitó la formación de un nuevo modelo de mujer mucho más activa, abierta al conocimiento y a la toma de decisiones (...) se desarrollaron nuevas disposiciones corporales y actitudes mentales que transmitieron las maestras a los estudiantes, que no pueden ser solo asumidas en términos disciplinarios, sino como la posibilidad de construcción de la nueva imagen de las maestras y mujeres laicas" (Goetschel,2007: 194).

21. En el sentido foucaultiano del término, a saber, como una "política general de [la] verdad" (Foucault, 1992).

22. Fundada por el Presidente Gabriel García Moreno en 1869 y con el nombre de "Protectorado Católico", después de diversos avatares fue remodelada y ampliada, volviendo a impartir docencia en enero de 1927, ya con la denominación de "Escuela de Artes y Oficios", y con la finalidad de "prepara[r] a un gran núcleo de la juventud, futura directora de los destinos del país, al abarcar en su seno al Establecimiento que educa al obrero, de ocasión para el entendimiento cordial entre las dos fuerzas que gobiernan el mundo", es decir, Capital y Trabajo (sic) (NN, 1927: 2). Dichas escuelas implantadas por todo el país entre 1872 y 1930, cumplían la doble función de: ofrecer una educación integral, sistemática y profesional a los futuros obreros cualificados para fomentar la industrialización del país y, al tiempo, "la protección y control de los pobres", en Pérez, 2010: 23-75, para la cita p. 51).

23. "Se ha creído y con razón que en la época actual, es principal deber de los dirigentes del país, atender a la educación de la mujer (...) El grave problema consistía en hallar la forma de ofrecer a la mujer medios superiores de vida a los estrechos y circunscritos de la costura, y que armonicen con los deberes que ella tiene que desempeñar en el hogar. Estas consideraciones hicieron que en la Escuela de Artes y Oficios se establecieran las industrias de Tejido de Mimbres y de Alfombras", (NN,1927: 6).

24. El primer vuelo postal en el Ecuador se realizó en noviembre de 1920 por el piloto italiano Elia Liut a bordo del avión nominado Telégrafo 1, uniendo las ciudades de Guayaquil y Cuenca. No obstante, no sería hasta "el 20 de marzo de 1929, cuando el Presidente Isidro Ayora inauguró la primera conexión aérea comercial regular entre Quito y Guayaquil, el servicio semanal fue asegurado entonces por una compañía privada, la S.E.D.T.A., filial de Lufthansa" (Deler,1994: 295-353, para la cita p. 331).

\section{RESÚMENES}

En los inicios de la producción propia ecuatoriana de noticias cinematográficas, Ecuador Noticiero Ocaña Film 1929 es pionera en este tipo de informativos. Apoyada y en gran medida subvencionada por el régimen de turno que vio en este tipo de imágenes una magnífica oportunidad 
propagandística, la que nos ocupa transmite a través de sus fotogramas una propuesta corporativa basada en el concepto hegemónico y elitista de civilización, y cuya constitución se basa en la ideología higienista. 0 , dicho de otra manera, se trataba de aplicar una biopolítica al cuerpo social a través, fundamentalmente, de un cierto control sobre el cuerpo humano en el que, y ampliamente comprendida, la disciplina higienista era fundamental. En ese momento, esta disciplina constituía simbólicamente y reforzaba orgánicamente el proyecto nacional y racista blanco-mestizo de las élites capitalistas y burguesas ecuatorianas.

Au début de la propre production équatorienne de nouvelles cinématographiques, Ecuador Noticiero Ocaña Film 1929 a été un pionnier dans ce type de nouvelles. Soutenu et largement subventionné par le régime actuel qui voyait dans ce type d'images une magnifique opportunité de propagande, celui qui nous concerne transmet à travers de leurs fotogrames une proposition corporative basée sur le concept hégémonique et élitiste de civilisation, et dont sa constitution repose sur l'idéologie hygiéniste. Ou, en d'autres termes, il s'agissait d'appliquer une biopolitique au corps social à travers, fondamentalement, un certain contrôle sur le corps humain dans lequel, et largement comprise, la discipline hygiénique était fondamentale. A cette époque, cette discipline constituait symboliquement et renforçait organiquement le projet national et raciste blanc-métisse des élites capitalistes et bourgeoises équatoriennes..

\section{ÍNDICE}

Mots-clés: biopolitique, hygiénisme, cinématographie équatorienne, images symboliques, capitalisme 27 septembre 2021

Palabras claves: biopolítica, higienismo, cinematografía ecuatoriana, imágenes simbólicas, capitalismo

\section{AUTOR}

\section{XAVIER PUIG PEÑALOSA}

Universidad del País Vasco/EHU (UPV/EHU), España.

Departamento de Filosofía de los Valores y Antropología Social.

Profesor Titular en Estética y Teoría de las Artes.

xavier.puig@ehu.eus 